\title{
Basin-Scale 3D Sedimentary Modelling: An Approach to Subdivide Baltic Sea Onshore Sediments for Land use and Construction
}

\author{
Antti E. K. Ojala · Joonas J. Virtasalo Elina Lindsberg • Mira Markovaara-Koivisto
}

Received: 24 February 2020/Accepted: 26 March 2021/Published online: 16 April 2021

(C) The Author(s) 2021

\begin{abstract}
Understanding the local stratigraphy and geometry of sediment units is necessary for successful 3D modelling and the prediction of ground behaviour and engineering-geological properties for urban land use and construction. A detailed 3D model of the main sediment units for the Rastaala basin in southern coastal Finland was constructed, combining a conceptual geological model and information from local drillhole logs and geotechnical drilling. The 3D modelling was based on a cross-section approach, where sediment units were defined on the basis of lithological boundaries that are of major geotechnical importance for land use and construction. The conceptual geological model was based on a sequence of events that characterize the late- and postglacial evolution of the Rastaala basin. The present study combines the allostratigraphy and lithostratigraphy of unconsolidated glacial, late-and postglacial sediment units in southern coastal Finland. It also investigates the appearance and distribution of sediment units in the Rastaala basin and compares modelling and visualization results for unit surfaces and solids using two
\end{abstract}

A. E. K. Ojala $(\bowtie) \cdot$ J. J. Virtasalo .

M. Markovaara-Koivisto

Geological Survey of Finland, P.O. Box 96, 02151 Espoo,

Finland

e-mail: antti.ojala@gtk.fi

E. Lindsberg

Geological Survey of Finland, P.O. Box 1237,

70211 Kuopio, Finland independent modelling software packages. Finally, information on the geotechnical properties of different sediment units in the Rastaala basin is provided so that they can be applied to other onshore regions with similar geological settings in the coastal Baltic Sea Basin.

Keywords 3D model - Clayey - Basin analysis . Lithostratigraphy · Allostratigraphy · Unconformity · Urban planning $\cdot$ Baltic sea $\cdot$ Finland

\section{Introduction}

Three-dimensional (3D) geological models that are based on boreholes, geological maps and crosssections are nowadays commonly used as tools to predict the lateral and vertical variability and continuity of sedimentary units and their engineeringgeological properties (e.g. Culshaw 2005; Devleeschouwer and Pouriel 2006; El May et al. 2010; Collon et al. 2015; Wang et al. 2018). One of the key challenges in this work is the identification of subsurface lithofacies that are relevant in each case, particularly in larger cities where underground planning and land use of areas with poorer ground conditions has increased. Studies on regional and local geology and understanding of sediment deposition processes can provide a practical framework to anticipate ground behaviour and to help make realistic assumptions on 
the properties of its materials (Fookes 1997). Visualization of 3D geology also enhances the usability of geological information among civil engineers, enabling them to better plan and manage the impacts of land use and infrastructure on the environment.

A typical need for urban geological mapping in cities along the Baltic Sea coastal areas is the distribution and properties of unconsolidated sediments that were deposited subaqueously during the history of the Baltic Sea Basin (BSB) history (e.g. Fang and Daniels 2006; Stapelfeldt et al. 2009; Ojala 2011). The composition and engineering-geological properties of BSB sediments depend on the sedimentary environment in which they were deposited (Gardemeister 1975). Different types of fine-grained sediment units can be spatially constrained and separated by unconformities and distinct lithological boundaries (e.g. Virtasalo et al. 2014a; Ojala et al. 2018). Unconformities also aid in correlating onshore and offshore sediment units across the shoreline, as was recently demonstrated on the Finnish south coast (Virtasalo et al. 2019). The land use of areas with unconsolidated sediments is, from an engineeringgeological point of view, concretized in aspects such as foundation depths and ground stabilization, acidification of the environment and heavy metal mobilization due to draining, as well as high construction costs due to unfavourable surface and/or subsurface geological characteristics (e.g. Gardemeister 1975; Fookes 1997; Edén et al. 1999; Stapelfeldt et al. 2009).

Using the Rastaala basin in southern coastal Finland as an example, this paper provides procedures and practices to integrate a conceptual geological model with drilling logs of glacial (till and sand), late glacial (silt and clay) and postglacial fine-grained sediments (silt, clay, organic-rich mud and peat) into a 3D model of sediment units with variable geotechnical characteristics. First, a type stratigraphy of finegrained sediments in the Rastaala basin is described, which is then compared with a basin-wide stratigraphic scheme for the offshore BSB. Second, the evolution of the Rastaala basin and the spatial distribution of its sediments is considered in the context of conceptual geological modelling. Third, the selected units are modelled for their 3D distribution in the study area, and finally, information on the geotechnical properties of the selected sediment units is presented. This paper offers a perspective on the engineering-geological properties, 3D modelling and subdivision of glacial, late- and postglacial sediments in the coastal Baltic Sea area for land use and construction purposes.

\section{Study Site}

The Rastaala study area $\left(60^{\circ} 14^{\prime} \mathrm{N}, 24^{\circ} 47^{\prime} \mathrm{E}\right.$, altitude 20-40 $\mathrm{m}$ above the present-day sea level (a.s.1.), $150 \mathrm{ha})$ is located in the city of Espoo, southern Finland, in the coastal area of the Baltic Sea (Fig. 1). The crystalline bedrock in the area is characterized by a deeply eroded base of Svecofennian orogeny and typically composed of granite, granodiorite, amphibolite and quartz feldspar paragneiss (Laitala 1991; Pajunen et al. 2008). The area has been covered several times by continental ice sheets during the Quaternary (e.g. Donner 1995). As ice sheets are effective agents of erosion, the numerous deposits and landforms currently found in southern Finland are related to the Weichselian glaciation spanning from ca. 117,000 to 11,700 cal BP (Svendsen et al. 2004; Stroeven et al. 2016). During the Late Weichselian, the Fennoscandian Ice Sheet (FIS) advanced over southern coastal Finland from the NNW (320-330 $)$ and extended to northern Germany in the south and to northwest Russia in the east. The advance of the FIS during the Late Weichselian removed most of the older sediments from southern Finland, and only fragments of pre-Late Weichselian deposits are therefore known (e.g. Hirvas et al. 1995). However, striations resulting from the preceding ice advances (ice-flow direction from north $350-10^{\circ}$ and northnorthwest 288-298 ${ }^{\circ}$ ) have been found (Repo et al. 1970). Nowadays, the landscape in the Rastaala area displays a combination of bedrock outcrops and Late Weichselian glacial deposits (till and sand) overlain by fine-grained sediments of the BSB and scattered terrestrial peat deposits (Fig. 1).

Till stratigraphic studies by Rainio and Lahermo (1976), Hirvas and Nenonen (1987), Bouchard et al. (1990), Hirvas (1991) and Hirvas et al. (1995), among others, provide a basis for the Weichselian and preWeichselian stratigraphy of the study area. Till deposits in southern coastal Finland are generally rather limited in size, typically massive to stratified in character, and the upper part of the sandy till has often been significantly washed by wave action and shore processes (Repo et al. 1970; Bouchard et al. 1990). 


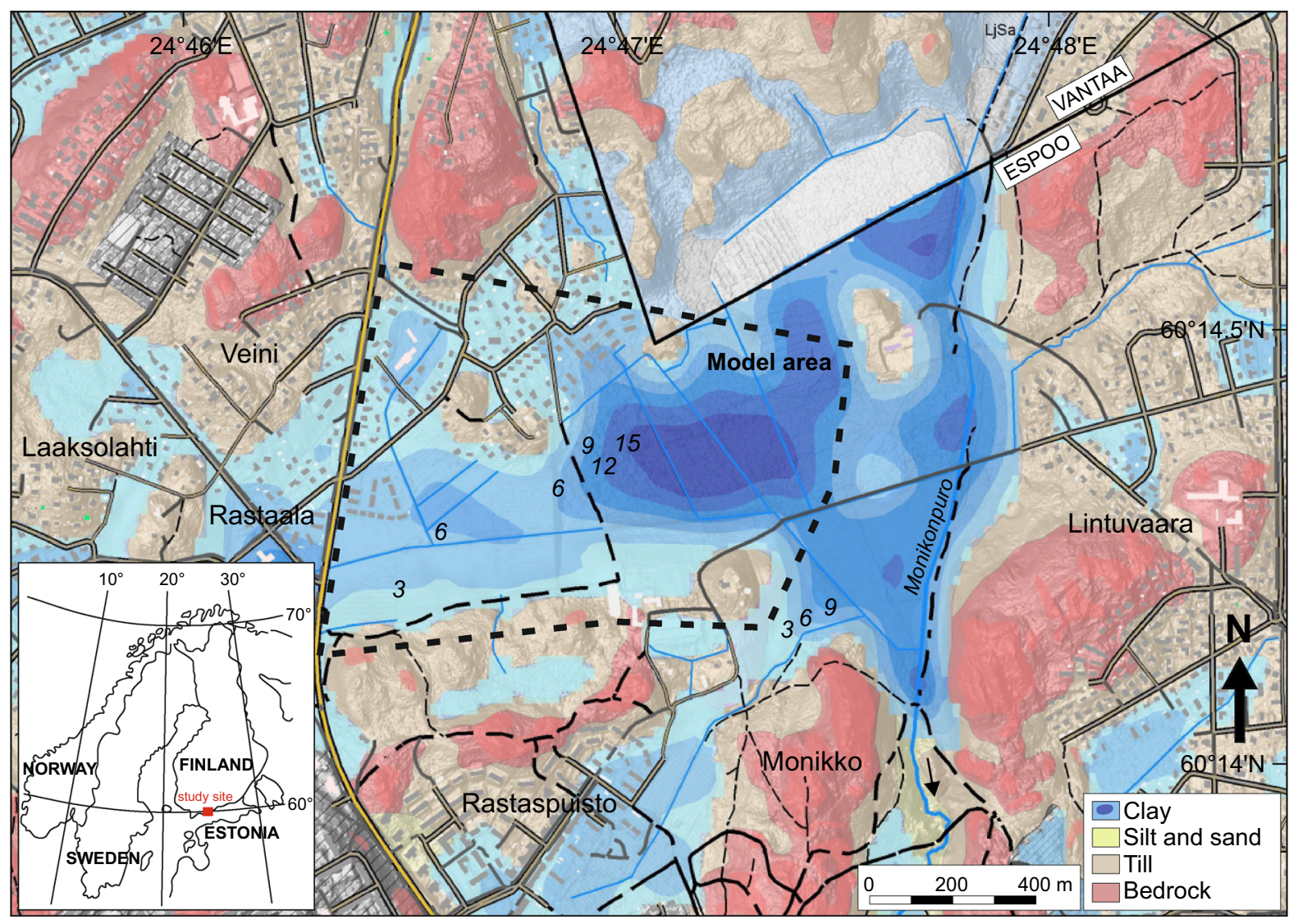

Fig. 1 Quaternary map with hillshaded digital elevation model (LiDAR DEM, National Land Survey of Finland) and the thickness of the fine-grained sediment succession (City of Espoo) at the Rastaala study site, southern coastal Finland. The

Hence, till cover is often found together with littoral silt and sand deposits that border bedrock outcrops and indicate postglacial shoreline reworking processes. Esker-like glaciofluvial landforms are absent in the study area, but levelled-down glaciofluvial sand and gravel deposits are rather common (Haavisto-Hyvärinen 1994; Repo et al. 1970). Glaciofluvial material is also often reworked by littoral processes.

The Rastaala study area was submerged at the time of deglaciation that took place during the Late Weichselian at around 13,000 cal BP (Stroeven et al. 2016) when FIS retreated north-westwards towards the Salpausselkä ice marginal zone. During and since the ice retreat, the BSB has gone through freshwater and brackish-water palaeoenvironmental phases (e.g. Virtasalo et al. 2007). The present study area was first a proglacial lake basin, then an ice-distal freshwater basin, and finally a sheltered embayment of the area consists of one larger sub-basin, where the thickness of finegrained sediments (indicated by blue-coloured isolines) exceeds $15 \mathrm{~m}$ and several smaller sub-basins

brackish-water BSB. The Rastaala basin was uplifted above the Baltic Sea level and isolated ca. 3500 cal BP as a results of glacioisostatic rebound (Hyvärinen 1999; Kakkuri 2012; Ojala et al. 2013). The isolation threshold lies at about $18 \mathrm{~m}$ a.s.l., draining towards the south via Monikonpuro creek between Lintuvaara and Monikko (Fig. 1).

Proglacial and postglacial fine-grained sediments (clay and silt) are the predominant superficial deposits in the entire Helsinki Metropolitan Area and cover about one-third of the land area. The same applies to the Rastaala area, where variable sedimentary environments occur in response to different processes such as uneven bedrock topography, late- and postglacial changes in the relative water level of the BSB, water stratification, salinity, the primary productivity of organic matter, and mineral matter supply and redeposition, which have resulted in the deposition of 
fine-grained sediments and reworking of glacial sediments in the basin (Gardemeister 1975; Ojala 2011; Virtasalo et al. 2007, 2014a). Today, the surrounding hills and slopes of the Rastaala basin are densely populated with detached houses, whereas the lower-lying area in the middle where the clayey section is thickest, has thus far remained in agricultural use or as fallow land (Fig. 1).

\section{Materials and Methods}

\subsection{Available Data and Stratigraphic Approach}

In order to discriminate sediment units and model their spatial distribution in the Rastaala area, we combined Quaternary maps of superficial deposits, thickness and lithological information on fine-grained sediment successions, and geotechnical drillings, which are typically used in civil engineering with the aim of determining the geotechnical subsurface properties. The applied maps of Quaternary deposits are available via online map services provided by the City of Espoo (https://kartat.espoo.fi/IMS/en/Map) and Geological Survey of Finland (https://gtkdata.gtk.fi/Maankamara/ index.html) with the mapping scale of 1:10 000 and 1:20 000, respectively. The boundaries of superficial deposits were revised with field reconnaissance and by using LiDAR-based (Light Detection And Ranging) digital elevation models (DEMs). The generalized thickness map of subsurface clayey sediments provided by the City of Espoo (https://kartat.espoo.fi/ IMS/en/Map) was used in an overall sediment thickness assessment.

The locations of lithological drill-holes and geotechnical drilling in the Rastaala area are presented in Fig. 2. Lithological logging of the fine-grained sediment characteristics and structure are based on 15 sediment sequences (Äijä1 to Äijä15, according to core logs by Ojala 2011), each 4-19 m long, that were taken with a piston corer (with a plastic high-density polyethylene tube, diameter $45 / 50 \mathrm{~mm}$ ) inside steel casing and operated by a GM-100 heavy-duty drill rig. Drill core sequences were taken as 1- or 2-m-long segments and stored at cold-room temperature $(+4$ ${ }^{\circ} \mathrm{C}$ ) prior to lithological analysis and subsampling. The lithology was logged by utilizing the facies codes for sediment description and characterizing the structures, inclusions, and contacts between lithofacies when detectable (e.g. Evans and Benn 2004). Mappable sediment units recognized in the drill cores were classified as lithostratigraphic units, which have gradational lower and/or upper contacts (Salvador 1994; NACSN 2005), or as allostratigraphic units, which are bounded by unconformities (NACSN 2005). The lithostratigraphic and allostratigraphic units were organized in a local stratigraphic scheme, with priority given into allostratigraphic units, following the combined use of allostratigraphy and lithostratigraphy (CUAL) approach (Räsänen et al. 2009).

A total of 1722 geotechnical drillings were available from the Rastaala area, of which about $75 \%$ were drill rig-operated Swedish weight soundings and $15 \%$ were percussion drillings that penetrate several meters into the bedrock. The rest of the data points represent vane testing and cone penetration tests with pore water pressure measurement (CPTU) to determine the geotechnical property of bearing capacity. About 1100 geotechnical drillings were located inside the presently modelled area (Fig. 2).

\subsection{Geological Framework and 3D Modelling}

In this study, a 3D model was constructed on the basis of sediment lithology, a careful selection of sediment units with different geotechnical properties, a conceptual understanding of the spatial distribution of the selected units and information from geotechnical drillings.

In the first step, a geological framework for the Rastaala basin was created based on published information about the regional to local geological history and sediments (e.g. Bouchard et al. 1990; Virtasalo et al. 2007; Ojala et al. 2013, 2018). The conceptual geological model provides a rational basis and common understanding of the sediment units in the area, as well as their geometry and connectivity (e.g. Cavero et al. 2016). The framework was then strengthened using lithological logs and geotechnical drillings in order to review the conceptual model and to decide which sediment units and unit boundaries are relevant from the perspective of their geotechnical behaviour. This approach was adopted from Knill (2003), who suggested that the principal basis of engineeringgeological modelling is to determine what the models are for, and then select and treat geological units in such a manner that they provide a consistent guide to the properties and behaviour of materials and masses. 


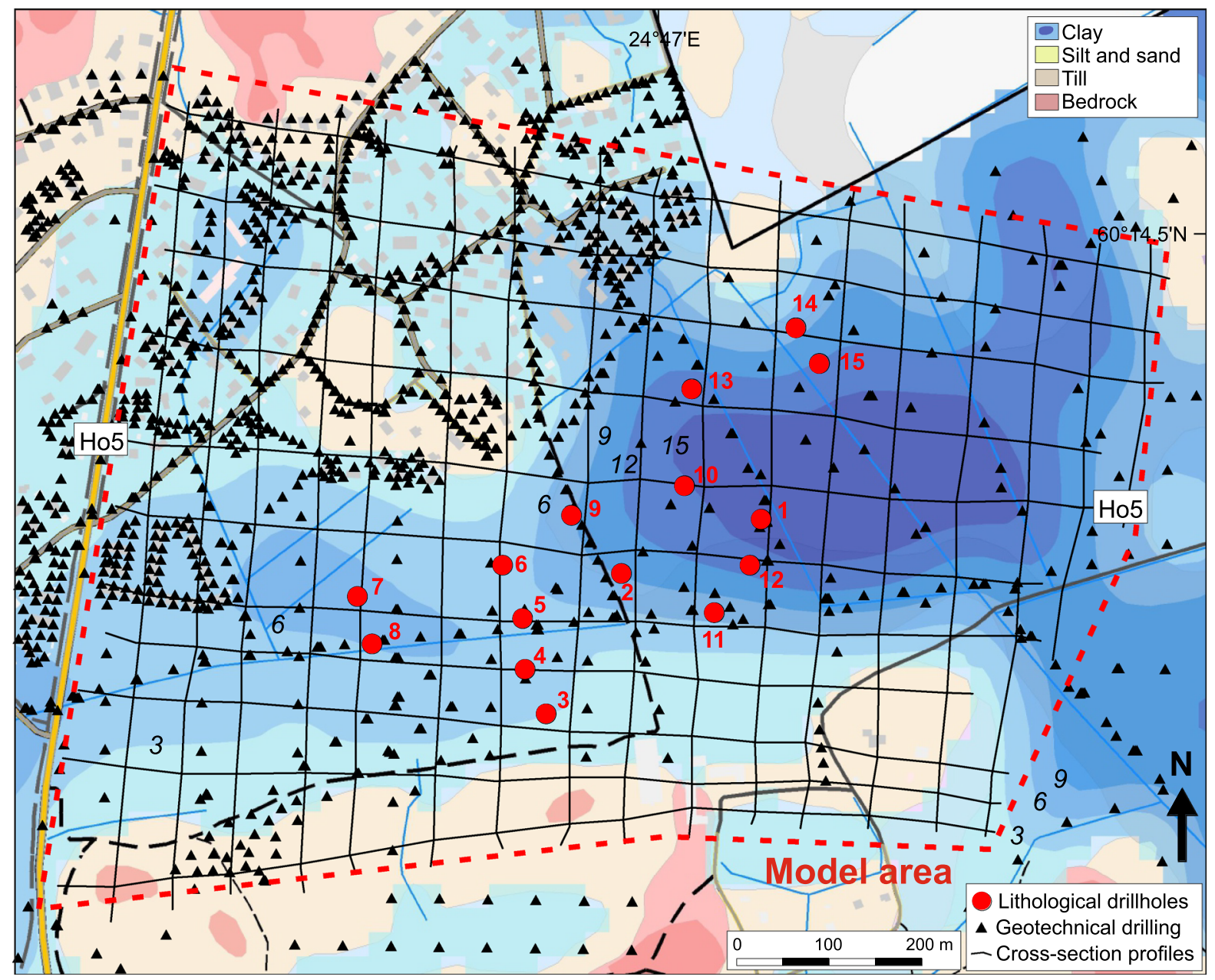

Fig. 2 The Rastaala basin area with the available lithological drillholes (Äijä1 to Äijä15 denoted with red dots and numbers) and geotechnical drillings provided by the City of Espoo (black triangles) used in 3D modelling. The red dashed line indicates the modelling area. The cross-sections of sediment units have been constructed along $11 \mathrm{~W}-\mathrm{E}$ and $17 \mathrm{~N}-\mathrm{S}$ oriented profiles indicated with black lines, with profile Ho5 specified

depositional environment of the selected and modelled sediment units.

In the second step, the conceptual geological model was improved through the integration of numerous geotechnical drillings and logs of lithological drillholes (Fig. 2). In the modelling, we first used Groundhog Desktop software version 1.10 developed by the British Geological Survey (BGS Groundhog ${ }^{\circledR}$ Desktop Copyright (C) BGS/NERC 2019) to display and edit the selected subsurface sediment units (Table 1). Unit boundaries were interpreted along vertical cross-sections that were predefined based on the location of lithological logs and geotechnical drillings (Fig. 2). In practice, 28 cross-section profile ical characteristics, classification and interpreted 
Table 1 Lithology and genesis of the sediment units modelled in the Rastaala basin

\begin{tabular}{|c|c|c|c|}
\hline Unit & Lithology & Genesis & Notes \\
\hline Unit 8 & Organic-rich mud and peat & Lacustrine and terrestrial & $\begin{array}{l}\text { Peat overlying mud, modified by anthropogenic land } \\
\text { use layer }\end{array}$ \\
\hline Unit 7 & Organic-rich mud & Brackish-water & Upwards increasing organic matter content \\
\hline Unit 6 & Sulphidic organic-rich mud & Brackish-water & Sulphide-bearing organic-rich mud \\
\hline Unit 5 & Silt (Sand) & Littoral redeposition & $\begin{array}{l}\text { Littoral silty to sand material, significantly reworked } \\
\text { in littoral processes }\end{array}$ \\
\hline Unit 4 & Clay & Glaciolacustrine & $\begin{array}{l}\text { Proglacial silty clay, varved clay and weakly- } \\
\text { layered clay }\end{array}$ \\
\hline Unit 3 & Sand (and gravel) & Glaciofluvial, ice-marginal & $\begin{array}{l}\text { Variable in character, sand and gravel, partially } \\
\text { reworked in littoral processes }\end{array}$ \\
\hline Unit 2 & Till & Glacigenic & $\begin{array}{l}\text { Mostly sandy till, significantly washed and loose in } \\
\text { character }\end{array}$ \\
\hline Unit 1 & Bedrock & Metamorphic & Granodiorite and quartz feldspar paragneiss \\
\hline
\end{tabular}

lines were set at 50-60 m apart and perpendicularly to create a dense grid of data points over the modelled area. Guided by the sounding data, the unit boundaries were defined at every $4-5 \mathrm{~m}$ along cross-sections, thus providing a total of about 5300 data points (35 data points per ha) for subsequent 3D surface and solid modelling. Considering that most data points contained several (up to eight) unit boundaries, the XYZ information in the dataset amounted to a total of about 24,000 data points. The data from Groundhog were then exported into two different software packages (i.e. Emerson E\&P SKUA-GOCAD ${ }^{\mathrm{TM}}$-Paradigm ${ }^{\circledR}$ and Leapfrog () ) to carry out 3D modelling and visualization in two separate platforms.

Modelling of 3D volumes with Seequent Leapfrog ${ }^{\circledR}$ ver. 4.4 started by defining the topography from the stratigraphic point set from chosen XY coordinates produced in Groundhog. The surface resolution was set at $10 \times 10 \mathrm{~m}$ to better conform to the observation data points. The model boundaries were set according to the topography layer. Other points defining the bottom of sediment units were introduced as points and surfaces created with vertices and triangles that define the 3D shape. The surface chronology was then determined and the points defining the bottoms of the selected units were chosen. After checking the contact surface chronology, the volumes were automatically generated and dynamically updated when additional information was added to the model.

Modelling of 3D volumes with Emerson E\&P SKUA-GOCAD ${ }^{\mathrm{TM}}$ _Paradigm ${ }^{\circledR} 15.5$ started with the densification of unit boundaries at every $5 \mathrm{~m}$. The uppermost unit boundary was draped onto the topography. A new point set was created by using points from cross-sections (base of unit) and unit boundaries. This point set was utilized in building the basal surface of sediment units with a $10 \mathrm{~m}$ raster size. The surface resolution was increased if the data discrepancy was higher than $0.1 \mathrm{~m}$. Cross-overs with the surface above were removed (minimum thickness $0.1 \mathrm{~m}$ ) and the derived basal surface was finally clipped by the unit boundary. Lower units were processed in the same way, where unit boundaries were draped onto the clipped basal surfaces above according to surface chronology. The vertical thickness of each unit was computed using a combination of DEM and clipped surfaces as a capping surface. Solids sediment units were created using unit basal surfaces and vertical thicknesses. The model boundary is slightly smaller than in the Seequent Leapfrog ${ }^{\circledR}$ model.

\section{Results and Discussion}

\subsection{Stratigraphy of the Rastaala Basin}

Superficial deposits in the Rastaala area can be subdivided into two 'main layers'. Underlying and also exposed on higher hills are glaciogenic sediments (till, gravel and sand) (Repo et al. 1970), which are generally highly suitable for the foundations of buildings and roads. These sediments were deposited during the Weichselian glaciation and are composed of lodgement and basal melt-out till and material 
sorted subglacially by meltwater activity (e.g. Bouchard et al. 1990). Their thickness can vary considerably within a limited area, depending on the bedrock topography, but is generally between 1 and $10 \mathrm{~m}$. Their typical facies, composition and lithostratotypes have been presented by Bouchard et al. (1990) and Hirvas et al. (1995), among others.

Above the glacial sediments lies littoral sand and silt from shoreline processes, as well lacustrine to brackish-water sediments composed of clay, organicrich mud and terrestrial peat. These postglacial finegrained sediments are essentially distributed in the lower-lying areas of the Rastaala basin, where their thickness can be up to $20 \mathrm{~m}$. A typical succession of fine-grained sediments in the Rastaala basin is presented in Table 2 and Fig. 3. A thin layer of sandy silt at the depth of $560 \mathrm{~cm}$ in the Äijä1 stratigraphy (Fig. 3) unconformably overlies poorly layered postglacial lacustrine silty clay. The sandy silt layer gradates upwards to dark sulphide-bearing organicrich mud in deep areas and to greenish-grey sulphidepoor organic-rich mud in shallower areas. This erosional sandy silt layer is a transgressive shelf sand sheet that was produced by the mid-Holocene marine flooding of the BSB, and marks the base of the brackish-water mud (Virtasalo et al. 2016; Ojala et al. 2018). This silt layer extends across the BSB in southern Finland, and was caused by a decreased sediment supply, winnowing and the redistribution of material from local coarse-grained deposits during the Litorina Sea transgression (Hyvärinen 1980). Previous marine stratigraphic studies have used the erosional base of this silt layer to subdivide Baltic Sea sediments into pre-incursion lacustrine and brackish-water units (Virtasalo et al. 2007, 2014a; Räsänen et al. 2009; Tsyrulnikov et al. 2012; Hyttinen et al. 2017; Jensen et al. 2017). The same erosional sandy silt layer has been identified in several onshore fine-grained sections in southern coastal Finland, including the Rastaala basin (Ojala et al. 2018). Importantly, the erosional base (unconformity) of this sandy silt layer was used in the present study to subdivide the studied depositional succession into lower and upper alloformations (Figs. 3, 4), and it also marks the boundary between units 4 and 6 in the 3D model (Table 1).

The upper alloformation is a succession of lithostratigraphic units: dark organic-rich mud, greenishgrey organic-rich mud, lacustrine organic-rich mud and peat. The contacts between the units are gradational. Importantly, the dark organic-rich mud is only found in the deepest parts of the basin, where the overall thickness of the fine-grained deposits exceeds $10 \mathrm{~m}$, and the thickness of the sulphidebearing layer is generally dependent on the total thickness of the clayey section (Fig. 4). The upper alloformation is bounded at its base by the erosional base of the sandy silt layer, and at the top by the present-day ground surface.

The lower alloformation is a succession of lithostratigraphic units: sandy till, glacioaquatic sand, glaciolacustrine varved clay/silt-sand and post-glacial weakly layered lacustrine silty clay. Glaciolacustrine varves with alternating sandy silt and clay couplet layers gradates to poorly layered postglacial silty clay. The nature of the contacts between till, glacioaquatic sand and glaciolacustrine varved clay/silt-sand cannot be unequivocally determined in the available drill cores, and the contacts are conservatively assumed to be gradational (e.g. Virtasalo et al. 2014a). The basal contact of the alloformation is tentatively assigned to the surface of the underlying crystalline bedrock, and the upper contact to the erosional base of the sandy silt layer at the base of the upper alloformation.

\subsection{The Conceptual Geological Model-Evolution of the Rastaala Basin}

The conceptual geological model of the Rastaala basin is based on sediment stratigraphy, as well as an understanding of the geological history of the area and the processes by which the sediment units were formed, defined in this research as different stages (Fig. 5). The unconsolidated sediments in the Rastaala area lie on the crystalline bedrock basin, which was probably deepened and from which old sediments were removed during the Weichselian glaciation (Hirvas and Nenonen 1987). At the same time, a till unit or units, possibly separated by intervening sand, were deposited by the southwards flowing ice sheet mainly, in glacial melt-out processes (stage 1) (Bouchard et al. 1990). In stage 2, during the retreat of the FIS from the area, meltwater flowed beneath the ice sheet, but because distinct channels to form eskers were absent, the meltwater formed a braided network of channels and deposited levelled-down glaciofluvial sand and gravel sediments (Repo et al. 1970; Bennett and Glasser 2009). Glacioaquatic sediments were 
Table 2 Lithological details of upper and lower alloformations in glacial to postglacial sections such as Äijä1 in the Rastaala basin. The black dashed line indicates the base of the brackish-water mud at the boundary between upper and lower alloformations

Upper alloformation

Lacustrine organic-rich mud and peat Structureless to fibrous, non-decomposed peat with roots of herbaceous plants and large fragments of woody plants. Underlain by dry lake mud with indistinct limno-telmatic contact

Greenish-grey organic-rich mud Soft greenish-grey clayey silt with small plant fragments. The sediment structure alternates between sharply laminated, diffusively bedded, and intensely burrow-mottled fabrics. Sharply laminated fabric is composed of millimeter-scale dark and pale couplet layers, which reflect the annual depositional cycle of phytoplankton during spring and summer, and intensified lithic deposition in late autumn and winter, respectively, and the absence of macrofaunal bioturbation under hypoxic conditions (Jokinen et al., 2015). Diffusively bedded fabric is composed of $0.5 \mathrm{~cm}$ and thicker layers with bioturbated or indistinctly biodeformed contacts, which reflect episodic deposition by storm-triggered flows and subsequent macrofaunal mixing (Virtasalo et al., 2014b). Intensely burrow-mottled fabric results from the complete overprinting of primary sedimentary structure by biodeformation and burrowing activities by macrofauna (Virtasalo et al., 2011)

Dark organic-rich mud Soft dark-grey clayey silt with small plant fragments. The dark color is due to the presence of iron monosulphides, which are oxidized and the dark coloring is lost within a few hours under exposure to the atmosphere. The sediment structure alternates between sharply laminated, diffusively bedded, and intensely burrow-mottled fabrics. Sharply laminated fabric is composed of millimeter-scale dark and pale couplet layers, which reflect the annual depositional cycle of phytoplankton during spring and summer, and intensified lithic deposition in late autumn and winter, respectively, and the absence of macrofaunal bioturbation under hypoxic conditions (Jokinen et al., 2015). Diffusively bedded fabric is composed of $0.5 \mathrm{~cm}$ and thicker layers with bioturbated or indistinctly biodeformed contacts, which reflect episodic deposition by stormtriggered flows and subsequent macrofaunal mixing (Virtasalo et al., 2014a, b). Intensely burrow-mottled fabric results from the complete overprinting of primary sedimentary structure by biodeformation and burrowing activities by macrofauna (Virtasalo et al., 2011)

Sandy silt A thin layer $(<2 \mathrm{~cm})$ of redeposited sandy silt an undulating erosional lower contact (unconformity) and a gradualbioturbated upper contact (Virtasalo et al., 2016; Ojala et al., 2018)

Lower alloformation

Glaciolacustrine varvite Rhythmically alternating light-grey silt (and fine sand) and grey clay layers. The light-grey coarsegrained (silt and fine sand) layers represent deposition of lithic material from glacial meltwaters during spring-summer. The grey clay layers represent suspension settling of the finer particles during winter ice season (Sturm, 1979; Zolitschka et al., 2015)

Glacioaquatic sand litologically not described in the Rastaala Äijä1 section, see e.g. Repo et al. (1970) and Bouchard et al. (1990) for description

Sandy till litologically not described in the Rastaala Äijä1 section, see e.g. Bouchard et al. (1990) for description

deposited in areas not in direct contact with glaciofluvial flows.

After the retreat of the FIS, the Rastaala area became a proglacial lake of the BSB, accumulating rhythmite deposits due to seasonal changes in meltwater discharge and the delivery of fine-grained sand, silt and clay into the basin along the glacier margin (stage 3) (De Geer 1912; Sauramo 1923). The structure and thickness of these glaciolacustrine varves are related to the proximity of the ice front and the seasonal delivery of meltwater in the basin. These sediments have a draped external form, and their composition gradationally shifts to finer-grained sediments upwards in the sequence. At the time of deposition, the highest shoreline was at about $120 \mathrm{~m}$ above the base of the Rastaala basin, and it rapidly regressed ( $4 \mathrm{~m}$ per 100 years on average) during the first millennia after deglaciation (Ojala et al. 2013). In stage 4, when the FIS had retreated some $500 \mathrm{~km}$ north of southern coastal Finland, the relative sea level in the Rastaala area had already dropped to $60 \mathrm{~m}$ a.s.l., which, considering the subsequent sediment fill and the elevation of the Rastaala basin, meant that the maximum water depth in the area was about $50 \mathrm{~m}$. The lowering of the relative water depth initiated littoral erosion of sandy till and glacioaquatic sand from the surrounding hills and slopes, which were transported and redeposited by bottom currents and shoreline processes towards the central deeper part of the basin (e.g. Nuorteva 1994).

Littoral erosion proceeded in stage 5. Owing to a near equilibrium between eustatic sea-level rise and isostatic land uplift, the relative sea level in southern coastal Finland was stable or slightly transgressive 


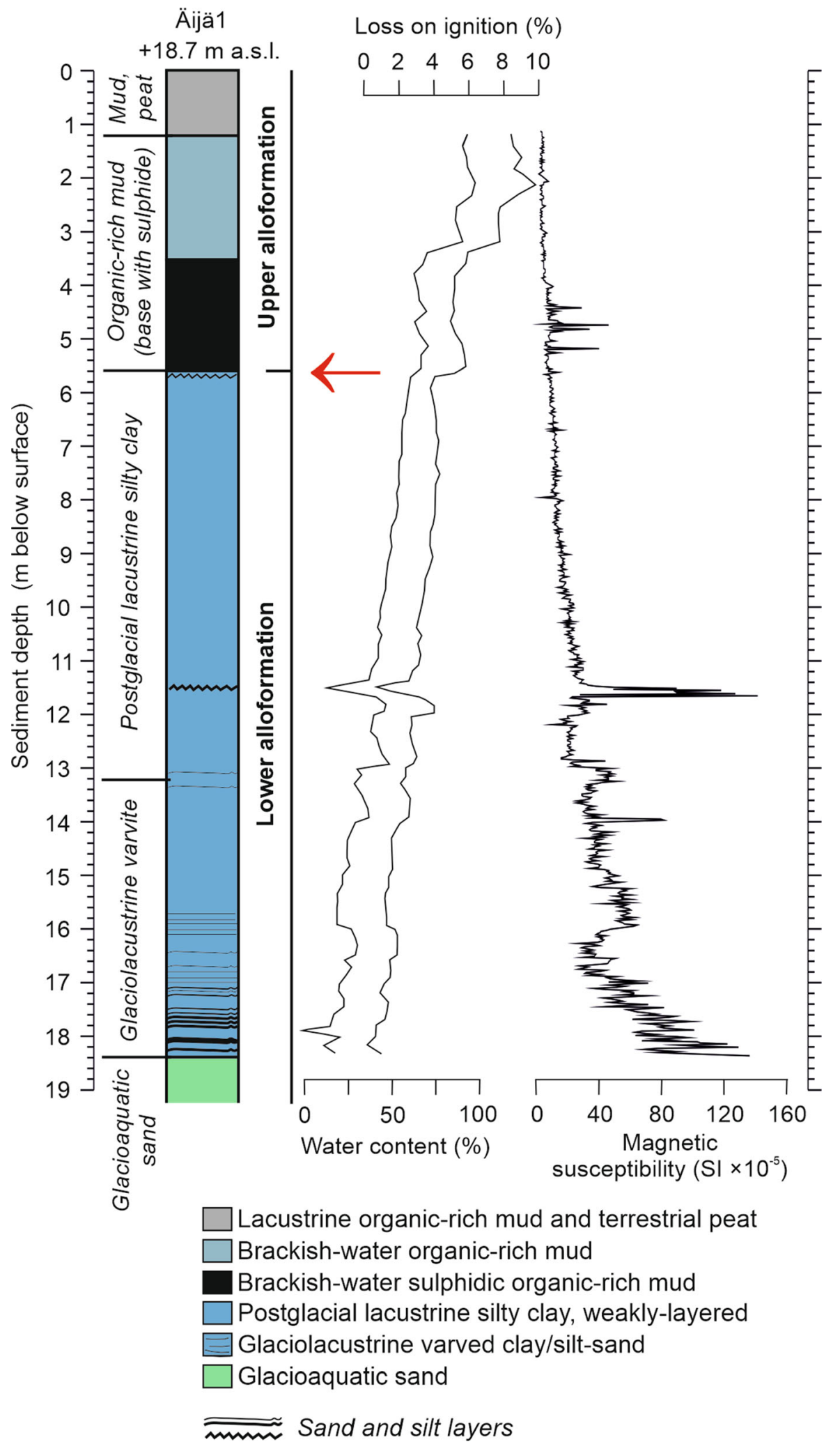


4Fig. 3 The lithological log of core Äijä1 from the middle of the Rastaala basin. It represents the typical succession of finegrained sediments in the Baltic Sea basin history in southern Finland. The red arrow indicates the base of the brackish-water mud at the boundary between upper and lower alloformations

between 7600 and 6500 cal BP (Hyvärinen 1980; Ojala et al. 2013). The hills around the Rastaala basin provided a bathymetric shelter from bottom current and wave activity, thus decreasing the sediment supply, winnowing and the redistribution of material while, on the other hand, enhancing the stratification of the water column and the consequent development of hypoxia in the deepest part of the basin. This resulted in the deposition of sulphide-bearing mud during the early phases of the brackish-water Baltic Sea (e.g. Virtasalo et al. 2016).

This was followed by a slow but continuous regression in stage 6, during which the Rastaala basin was isolated from the BSB around 3500 cal BP. With isostatic land uplift and the isolation of the Rastaala basin from the sea, the marine influence and sulphate levels in the basin waters declined, and the colour of deposited sediment also turned greenish-grey. Eventually, more organic sediments from autochthonous production combined with an influx of allochthonous material from the surrounding catchment filled in the lake, causing water loss during basin succession. Over time, the infilled lake basin transformed into a peat bog until anthropogenic activities, such as ditching and

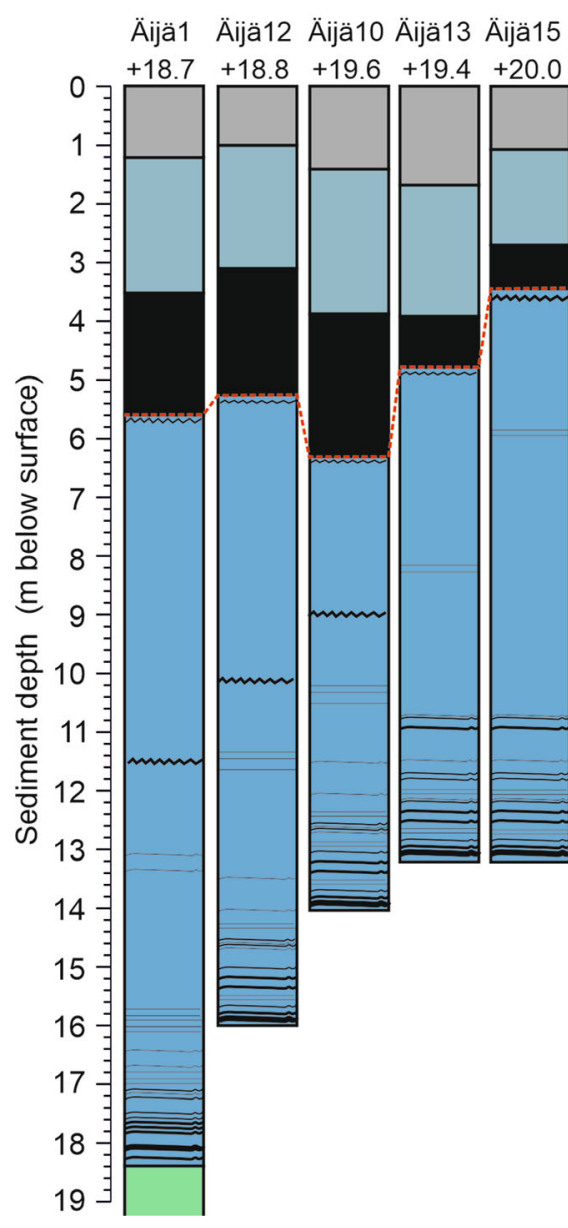

Fig. 4 Lithological logs from the Rastaala basin show that the composition and structure of the fine-grained deposits vary substantially with depth and also between coring locations. The red dashed line indicates the base of the brackish-water mud at the boundary between upper and lower alloformations 
Stage 1: Weichselian glaciation

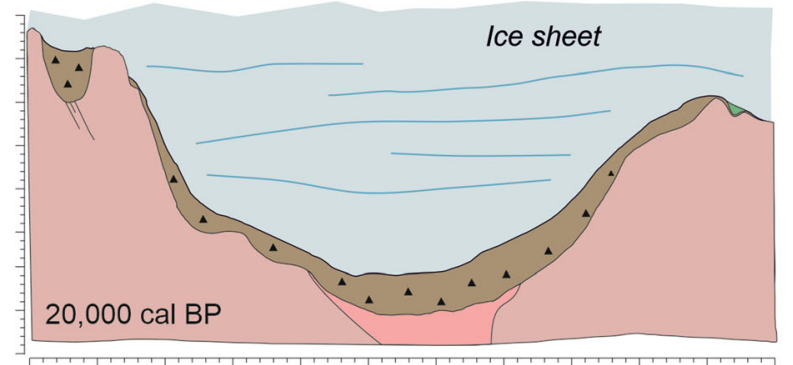

Stage 3: Proglacial lake basin (Baltic Ice Lake)

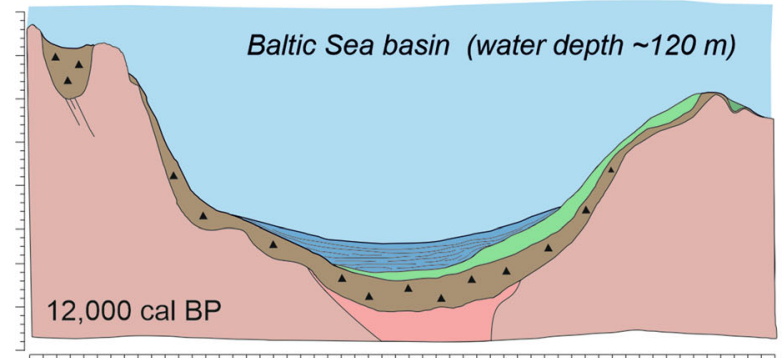

Stage 5: Brackish-water hypoxic basin (Litorina Sea)

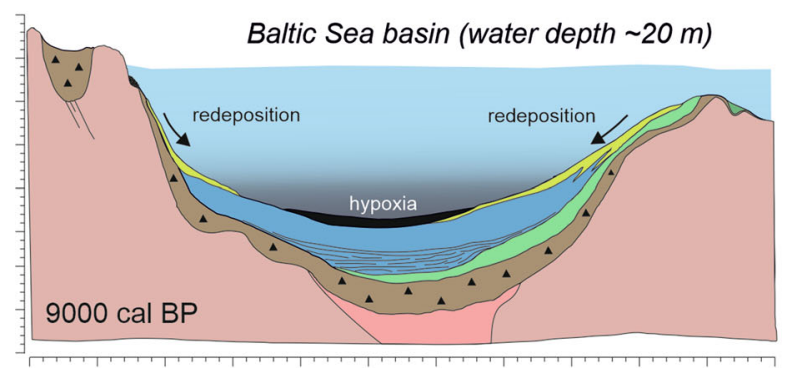

Stage 7: Lacustrine to terrestial basin

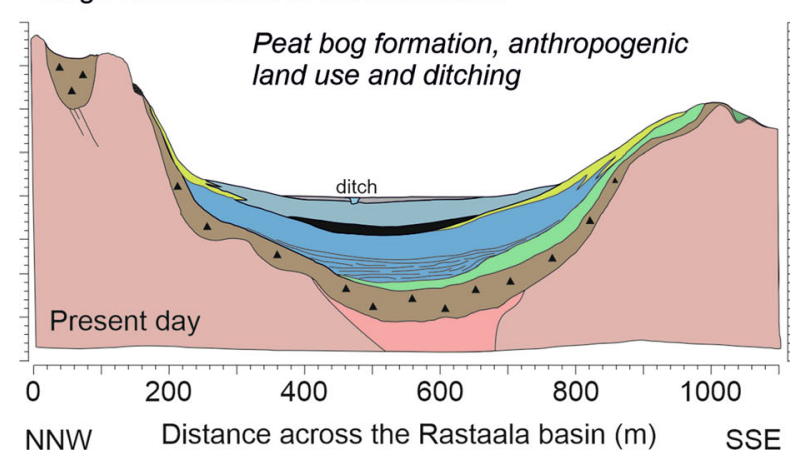

Stage 2: Weichselian deglaciation

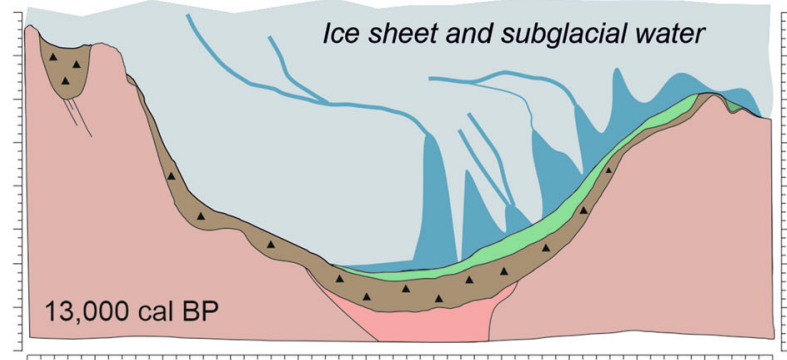

Stage 4: Distal lake basin (Ancylus Lake)

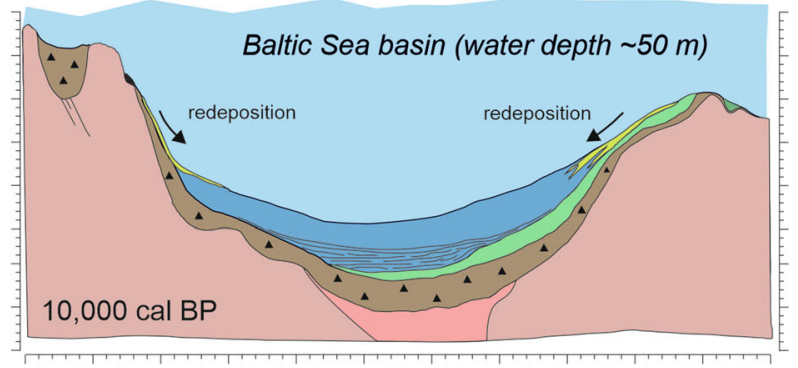

Stage 6: Isolation from Baltic Sea

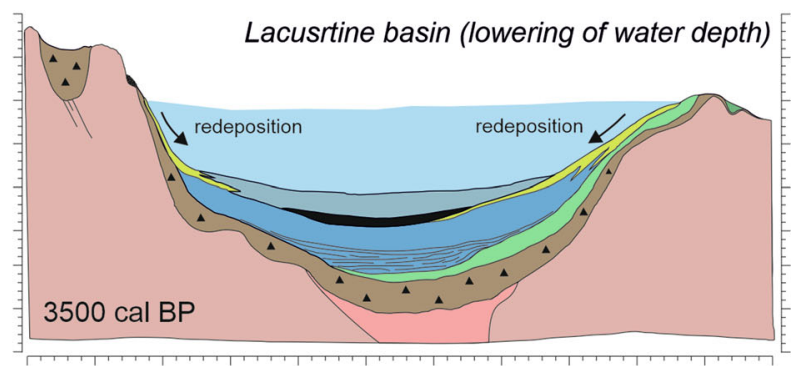

Fig. 5 Simplified model of the evolution and deposition of glaciogenic and postglacial fine-grained sediments in the Rastaala basin since the Late Weichselian glaciation. The sediment units of this conceptual model are given in Table 1

grazing, lowered the water table and impacted on the surface cover (stage 7). 
4.3 3D model of sediment units in the Rastaala basin

The stepwise modelling with multi-source data integration and the cross-section approach was found to be very suitable in the Rastaala case for several reasons. First, a large number of data points from lithological and geotechnical drillings provided a dense grid of subsurface characteristics, thus allowing the quantification of volumetric models, both explicitly and from the viewpoint of basin evolution. Second, despite the variable genesis of glacial and postglacial origin, the sediment units in the Rastaala basin lie in a rather simplistic manner compared with many other geological environments (e.g. Matildes et al. 2010; Yan-lin et al. 2011; Collon et al. 2015). The sediments are mostly arranged as beds and superimposed surfaces of different types that have been deposited in parallel or closely parallel to the basement surface, thereby enhancing the development of a stratigraphic classification scheme in association with a conceptual model. Third, the spatial continuation of the selected units is well understood and their boundaries unambiguously identified, followed and controlled with multi-source data integration. An example of a crosssection with geotechnical drillings is presented in Fig. 6, where the overlying fine-grained units are easily distinguished from the underlying coarser sediments. In addition, intersections of cross-sections (altogether 172 points; see Fig. 2) provided useful places to ensure that the modelled units lie at the same depth. Another important advantage of using a crosssection approach was the easy identification of possibly erroneous unit boundaries in the basin type of environment, which allowed better control over data feasibility for 3D modelling.

The 3D spatial models of the selected sediment units constructed with Leapfrog ${ }^{\circledR}$ and Emerson E\&P SKUA-GOCAD ${ }^{\mathrm{TM}}$ _Paradigm ${ }^{\circledR}$ for the Rastaala basin are presented in Figs. 7, 8. They indicate that the lower-lying area in the east has the thickest section of fine-grained sediments ( $>20 \mathrm{~m})$, which corresponds to the location of a bedrock surface depression. It seems evident that the bedrock depression has effectively trapped postglacial sediments during the evolution of the BSB (Fig. 6). The average thickness of postglacial fine-grained sediments (units 4-8) in the entire model area is about $6 \mathrm{~m}$. Below the fine-grained deposits lies 1-3-m-thick layer of sandy till (unit 2) and glacioaquatic sand (unit 3) that extends over most of the modelled area, except for higher-lying peaks of bedrock outcrops in the peripheral areas. Littoral silt/ sand (unit 5) that interlays units 4 and 6 is mostly less than $1 \mathrm{~m}$ thick. It occurs on the slopes of peripheral bedrock outcrops and is absent or very thin $(1-5 \mathrm{~cm})$ in the middle of the basin.

Considering the geometry of organic-rich brackishwater mud in the Rastaala basin, it is evident based on both models that the sulphidic organic-rich mud (unit 6) lies in the central part of the deepest basin in the east, with a variable thickness of $0.1-2.0 \mathrm{~m}$, and is entirely covered by organic-rich brackish-water mud (unit 7) and lacustrine mud and terrestrial peat (unit 8) (Figs. 6, 7, 8). However, in the Leapfrog-based 3D model the spatial distribution of unit 6 'leaks' towards the peripheral areas of the deepest basin (Fig. 7), which is not accurately modelled, because this unit is not exposed to the surface anywhere in the Rastaala area. The complete coverage of unit 6 by units 7 and 8 is clearly presented in cross-section profiles (Fig. 6) and accurately modelled by the GOCAD-based approach (Fig. 8). In the middle of the basin, the upper boundary of unit 6 lies at a depth of about 4-5 $\mathrm{m}$, whereas towards the margins it is closer to the surface (at a depth of about $1 \mathrm{~m}$ ) (Figs. 4, 6). According to the Leapfrog 3D model, the area covered by unit 6 is about $28.2 \%$ of the modelled area, which is an overestimate because of the 'leaking' towards peripheral areas. Cropping of the unit 6 area was more efficiently accomplished with GOCAD 3D modelling, where the unit 6 area totals $167306 \mathrm{~m}^{2}$, thus being $23.8 \%$ of the modelled area. Regarding the volume, the Leapfrog 3D model again provides a slight overestimate $(16.7 \%)$, which is higher than the volume $(13.6 \%)$ modelled by GOCAD.

In general, the main characteristics of these two 3D models agree well and provide clear insights into the subsurface characteristics. This agreement is probably enhanced by the rather simple geology, dense grid of unit observations and the limited size of the modelling area. The minor differences in the spatial distribution of unit areas and volumes between these two 3D models are mostly related to: (i) the spatial accuracy of the horizontal unit boundaries ('croplines') and minor differences between the model outer boundaries, (ii) the way in which the modelling programs can handle intersecting layers and solids, and (iii) the algorithms according to which unit surfaces were calculated. The 


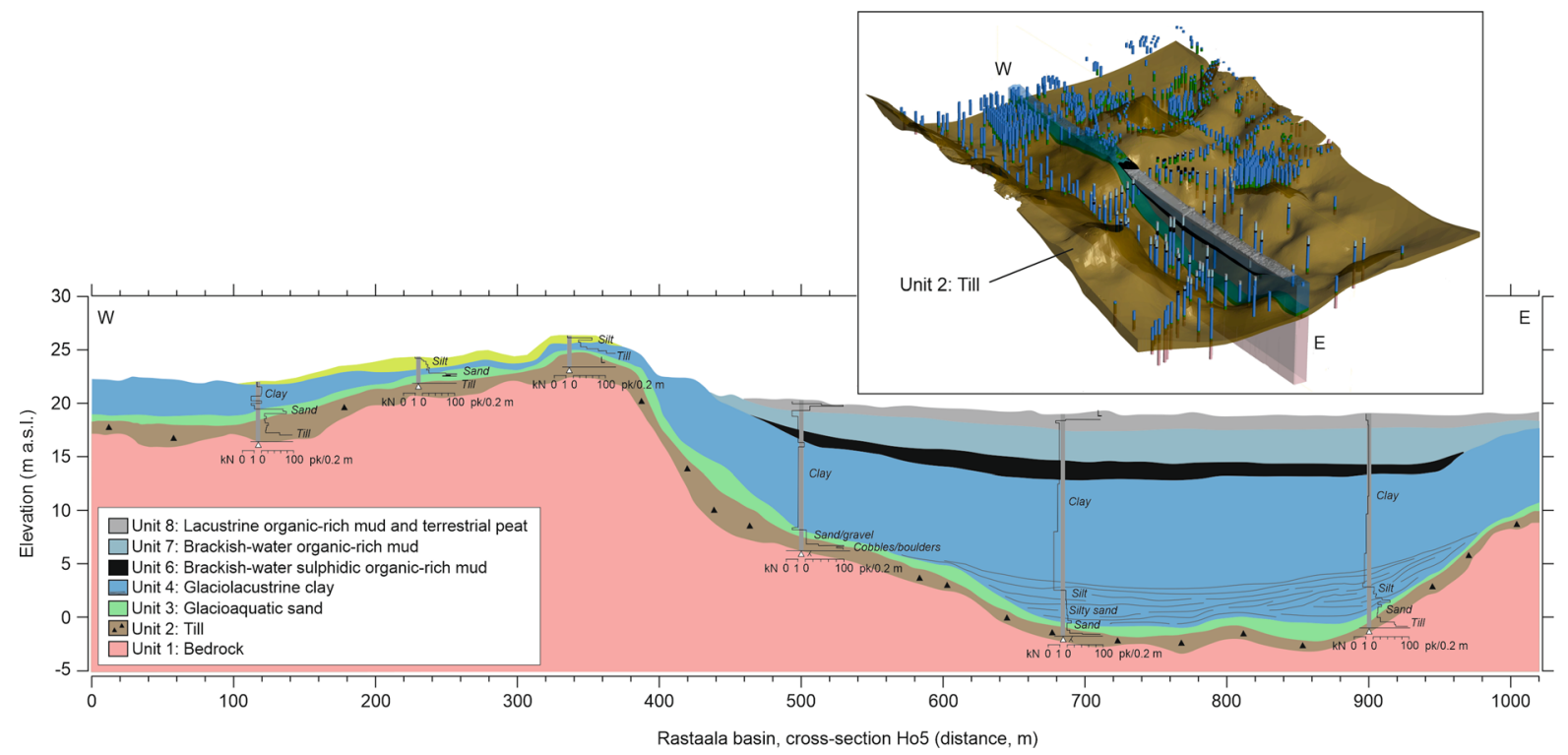

Fig. 6 W-E cross-section profile across the Rastaala basin with the modelled 3D sediment units and selected Swedish weight sounding profiles and their on-site lithological interpretations

most significant deviation of the 3D object representation between these two methods is that the GOCADbased model generated unit 7 more reliably towards the western sector of the modelling area, where the coverage of organic-rich mud is thin and discontinuous. This discrepancy is not due to missing boundaries or sedimentary strata, but rather related to difficulties in constructing the spatial geometry of unit 7 with the desired level of accuracy using Leapfrog ${ }^{\circledR}$. As a consequence, the average thickness of this unit also differ between these 3D models (Table 3).

Another inconsistency in the modelled areas and volumes between Emerson E\&P SKUAGOCAD $^{\mathrm{TM}}$ _Paradigm ${ }^{\circledR}$ and Leapfrog ${ }^{\circledR}$ 3D models concerns unit 4 , which is composed of glaciolacustrine and postglacial lacustrine clay (Table 3 ). This divergence of about $1 \mathrm{~m}$ in average thickness of unit 4 is expected because with Leapfrog ${ }^{\circledR}$, the silty to sandy unit 5 was modelled as a cross-cutting surface and its volume was stacked in unit 4 , whereas with GOCAD, both units were represented as individual solids in the 3D model. This outcome is considered as a good example of $3 \mathrm{D}$ modelling technologies where, depending on the case and applied modelling software, complicated objects are sometimes better compiled as 3D surfaces and in others cases as volumetric grids (e.g. Kessler et al. 2008). This is simply due the given. The brown solid in the upper right image represents the modelled till bed in the basin

complexity of inherent geological situations, as discussed by Knill (2003) and Culshaw (2005).

Similarly to 2D geological maps, the limits and uncertainties of the depth and lateral extent (3D) of modelled sediment units are mostly associated with (i) the natural variability in the data, including interpretations of drill core information, and (ii) the uncertainties in modelling procedures, including simplifications and interpolation methods (e.g. Evans 2003; Culshaw 2005). Probably the most convenient way to avoid these uncertainties is to utilize geological maps that define the lateral extents of geological units and apply a range of thickness constraints, which results in more realistic 3D geometry. In the Rastaala case, these potential shortcomings were more efficiently eliminated by using the GOCAD model.

Another point regarding the accuracy of 3D models is related to the accuracy and limitations of the geotechnical drilling data. Is seems clear that the uncertainties and heterogeneities are reduced by having a large number of closely-spaced observations, from which the operator is able to select the most representative ones without losing the appropriate resolution. Having reviewed the abundance of geotechnical data from the Rastaala basin, however, we agree with Culshaw (2005), who concluded that interpreting all units from every available borehole 


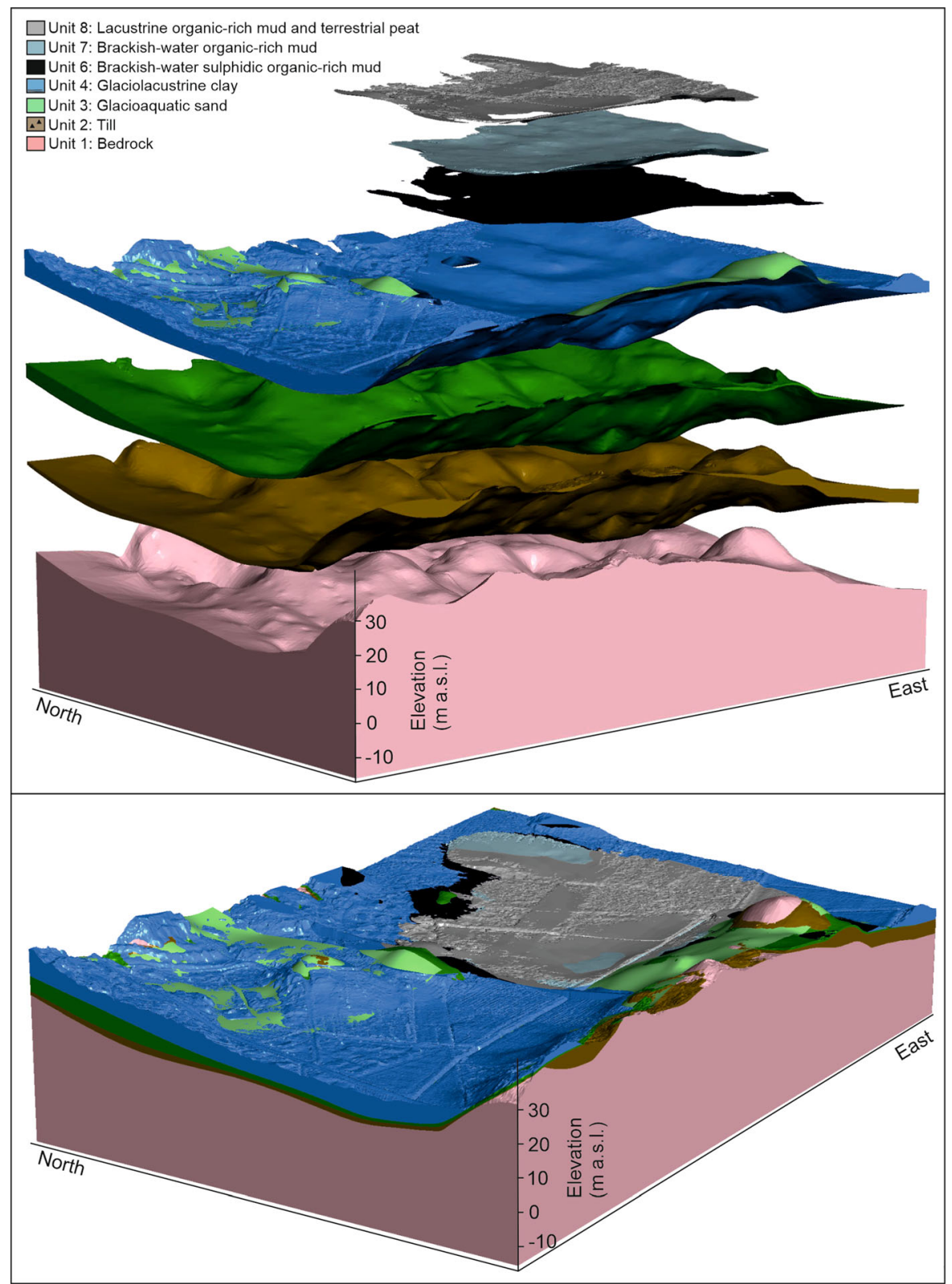

Fig. 7 A 3D Leapfrog spatial model for the Rastaala basin (below) and an exploded view of the selected sediment units discussed in the text and provided in Table 1 (above). The location of the model area in Espoo, Finland, is shown in Fig. 1

will probably produce a poorly constrained 3D model (or not model at all) and an inhomogeneous dataset with inconsistent reliability. In the 3D modelling of Rastaala, scattered information was disregarded and only the most relevant data were kept to ensure smooth and efficient 3D modelling of the sediment units in the basin (see Culshaw 2005). However, we emphasize that the large number of geotechnical drillings in the
Rastaala area (Fig. 2) allowed us to do this, which is often not the case. Furthermore, as pointed out by Knill (2003), the relevance of disregarding or full usage of all data points heavily depends on the context and the purpose of 3D models.

It is also notable that all till layers have been combined as one unit (unit 2) in the present 3D model (Table 1), although Bouchard et al. (1990), among 


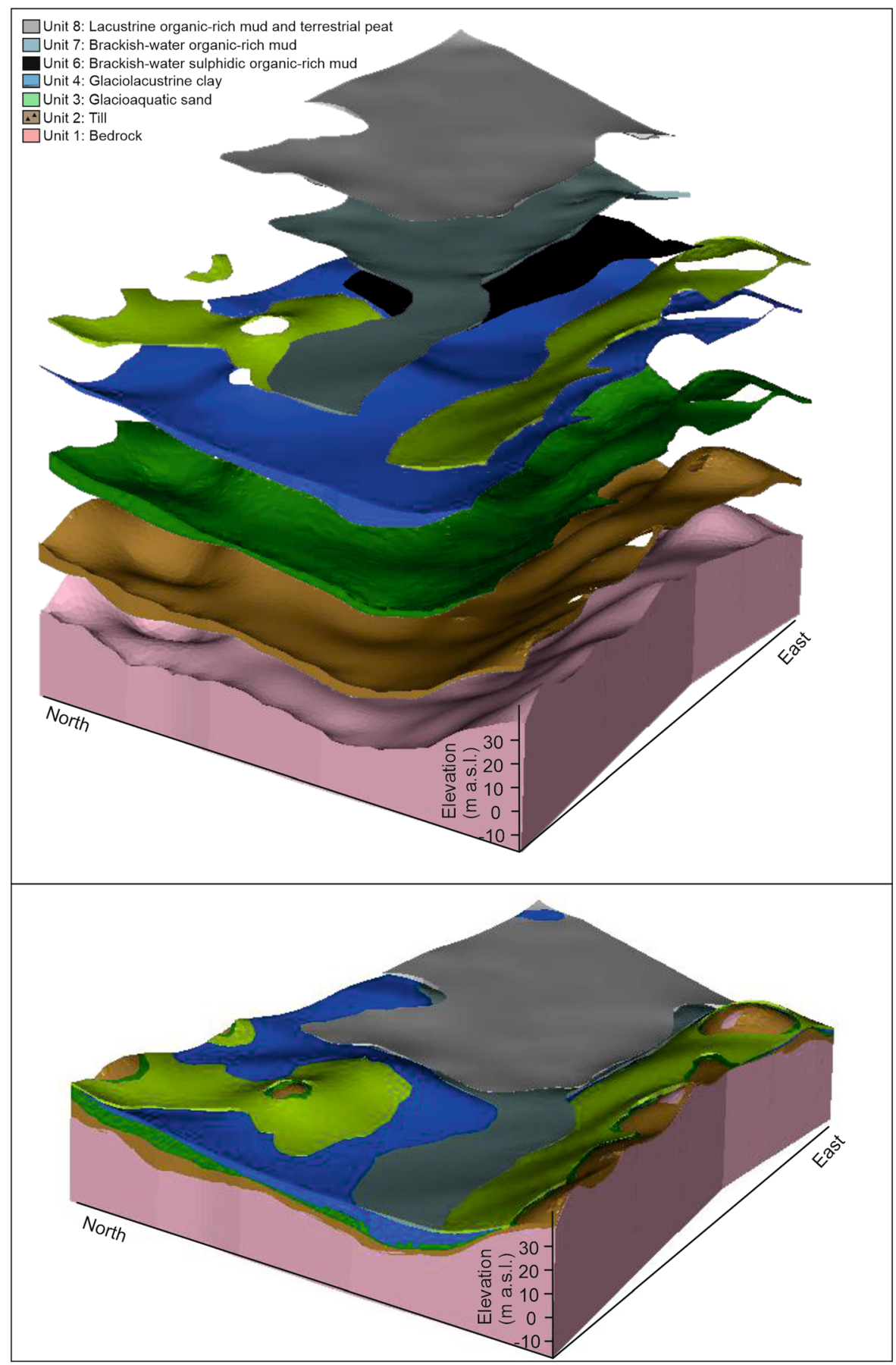

Fig. 8 Emerson E\&P SKUA-GOCAD ${ }^{\mathrm{TM}}$ _Paradigm ${ }^{\circledR}$ spatial model for the Rastaala basin (below) and an exploded view of the selected sediment units discussed in the text and provided in

others, report more a diverse glacial lithostratigraphy. Such variations would be difficult and subjective to determine based on soundings alone, especially when
Table 1 (above). The location of the modelled area in Espoo, Finland, is shown in Fig. 1

the results are dependent the equipment used and the drilling data are compiled over several decades. Moreover, most drillings terminated either in a denser 
Table 3 Areas and volumes of the sediment unit surfaces and solids in the Rastaala basin based on the present Leapfrog ${ }^{\circledR}$ and Emerson E\&P SKUA-GOCAD ${ }^{\mathrm{TM}}$-Paradigm ${ }^{\circledR}$ 3D modelling. Because of the slightly different model extensions, the area and volume characteristics were in both cases calculated as percentages of the bedrock surface and till volume, respectively

\begin{tabular}{|c|c|c|c|c|c|c|}
\hline \multirow[t]{2}{*}{ Unit } & \multicolumn{3}{|c|}{ Leapfrog $® 3 D$ model } & \multicolumn{3}{|c|}{$\begin{array}{l}\text { Emerson E\&P SKUA-GOCAD }{ }^{\mathrm{TM}} \text { - } \\
\text { Paradigm }{ }^{\circledR} 3 \mathrm{D} \text { model }\end{array}$} \\
\hline & Area, $\%\left(\mathrm{~m}^{2}\right)$ & Volume, $\%\left(\mathrm{~m}^{3}\right)$ & $\begin{array}{l}\text { Average } \\
\text { thickness } \\
\text { (m) }\end{array}$ & Area, $\%\left(\mathrm{~m}^{2}\right)$ & Volume, $\%\left(\mathrm{~m}^{3}\right)$ & $\begin{array}{l}\text { Average } \\
\text { thickness (m) }\end{array}$ \\
\hline Unit 8: Organic-rich mud and peat & $22.8(232,160)$ & $15.8(205,555)$ & 0.89 & $31.6(222,591)$ & $23.3(200,603)$ & 0.79 \\
\hline Unit 7: Organic-rich mud & $23.6(240,120)$ & $35.1(455,440)$ & 1.90 & $40.6(285,826)$ & $52.0(448,769)$ & 1.18 \\
\hline Unit 6: Sulphidic organic-rich mud & $28.2(286,790)$ & $16.7(216,930)$ & 0.76 & $23.8(167,306)$ & $13.6(117,321)$ & 0.65 \\
\hline Unit 5: Silt (sand) & $21.2(214,585)$ & N/A & N/A & $29.5(207,423)$ & $18.1(155,964)$ & 0.60 \\
\hline Unit 4: Clay & $79.3(807,850)$ & $307.1(3,984,900)$ & 4.93 & $88.7(624,269)$ & $328.1(2,830,500)$ & 3.93 \\
\hline Unit 3: Sand (and gravel) & $87.4(890,100)$ & $80.9(1,049,700)$ & 1.18 & $93.0(654,953)$ & $72.3(624,047)$ & 0.90 \\
\hline Unit 2: Till & $91.2(929,450)$ & $100(1,297,500)$ & 1.40 & $99.5(700,633)$ & $100(862,657)$ & 1.22 \\
\hline Unit 1: Bedrock & $100(1,018,650)$ & N/A & N/A & $100(703,993)$ & N/A & N/A \\
\hline
\end{tabular}

layer at the target depth or on a pebble or boulder in till, and do not provide exact information about the depth of the bedrock (unit 1) surface. Consequently, the modelled bedrock surface is based on a lesser number of observations than the base of the finegrained sediments (unit 4), for example.

\subsection{Geotechnical Characteristics of the Selected Sediment Units}

One of the main objectives of engineering-geology is to characterize the geological units in terms of their material properties, and to incorporate the available sedimentological and geotechnical data into 3D models for urban construction and land use (Knill 2003; Kessler et al. 2008). The contents of the presently modelled sediment units in the Rastaala study area include two important aspects: (i) the key lithological characteristics (Table 1) and (ii) the spatial geometry of objects in terms of points, surfaces and solids. For the reasons discussed above, such as the amount of sedimentological detail and the heterogeneity of geotechnical data, 3D models inevitably involve the simplification of units and their spatial arrangement in a basin. Therefore, the careful selection and refinement of the basic building blocks for geological 3D models is of fundamental importance, as discussed by Culshaw (2005) and Wu et al. (2005), among others. Combined with the rapid development of information technology and an ever-increasing amount digital geo- data, a thoroughly considered conceptual 3D model of the subsurface deposits has brought geological understanding to a situation in which the production of 3D spatial models for land use and construction is feasible, even under complex geological conditions (e.g. Culshaw 2005; Yan-lin et al. 2011). However, a prerequisite for such an approach is that it needs to be based on an understanding of the geotechnical characteristics of the modelled sediment units.

The geotechnical properties of sediment units (Table 1) modelled in the present study for the Rastaala basin are presented in Fig. 9. The analyses are based on a comparison between the subsurface 3D models and data obtained from Swedish weight soundings and shear vane tests.

As earlier shown by Gardemeister (1975), Stapelfeldt et al. (2009), Ojala (2011) and Ojala et al. (2018), the glacial (units 2-3) and postglacial (units 4-8) sediment units are well discriminated with the Swedish weight sounding tests in this type of sedimentary basin. The penetration resistance is significantly lower in softer fine-grained sediments (units 4-8) than in coarser glacial sediments, as indicated by an example section (Fig. 10) and the overall geotechnical characteristics (Fig. 9). It is noteworthy that screw point penetration into brackish-water organic-rich mud (units 6 and 7) often occurs with weights of $0.2-1 \mathrm{kN}$ during sounding, whereas penetration into clayey sediments (unit 4) often requires full weights $(1 \mathrm{kN})$ and sometimes 
simultaneous turning of the rod (Fig. 9a,b). In the peripheral areas of the Rastaala basin with a total sediment thickness of about $7 \mathrm{~m}$ or less, a rotation of 5-20 halfturns $\mathrm{m}^{-1}$ was typically needed for penetration into clayey unit 4, especially in the upper part of the unit (Figs. 9a,b and 10b). In addition, an anomalous increase in halfturns was frequently detected in the lower parts of unit 4 , where the proportion of silt and/or fine-grained sand increased. Below this, in sand/gravel (unit 3) and sandy till (unit 2), the penetration resistance was further increased and the number of rotations needed for cone penetration varied between 20 and 60 halfturns $\mathrm{m}^{-1}$ without significant differences between units 2 and 3 (Fig. 9b).
Several halfturns were also often needed to penetrate into the uppermost unit 8 , which contains silty humus and/or dry crust, especially in areas that are not covered by moist peat and lacustrine mud (unit 8) in the middle of the basin (Fig. 10). Furthermore, in many cases, layer(s) of littoral sand (including unit 5) can be detected in coring diagrams if they are thick enough to be registered with penetration resistance (Fig. 10c).

Based on the present results, it is evident that the exact boundaries of almost similar sediment types are difficult to register through Swedish weight soundings with or without simultaneous turning of the rod. For example, discrimination between coarse silt in the

\section{SWEDISH WEIGHT SOUNDINGS}
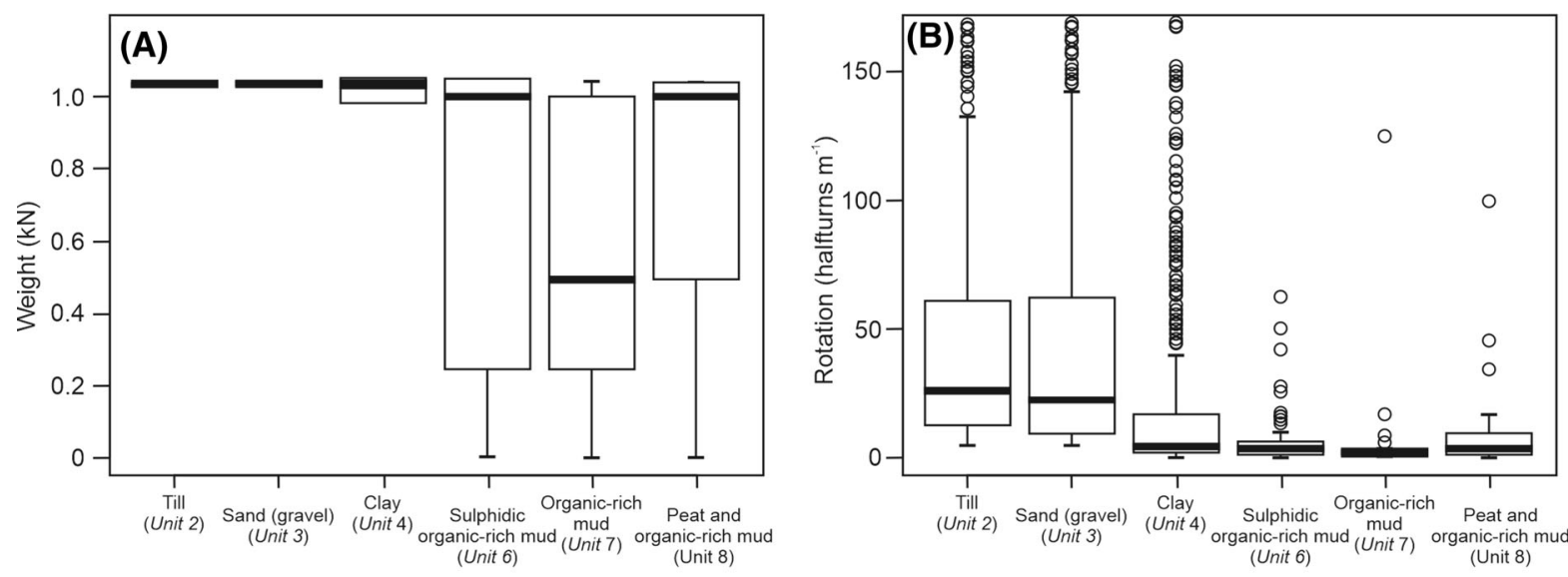

\section{VANE TESTS}
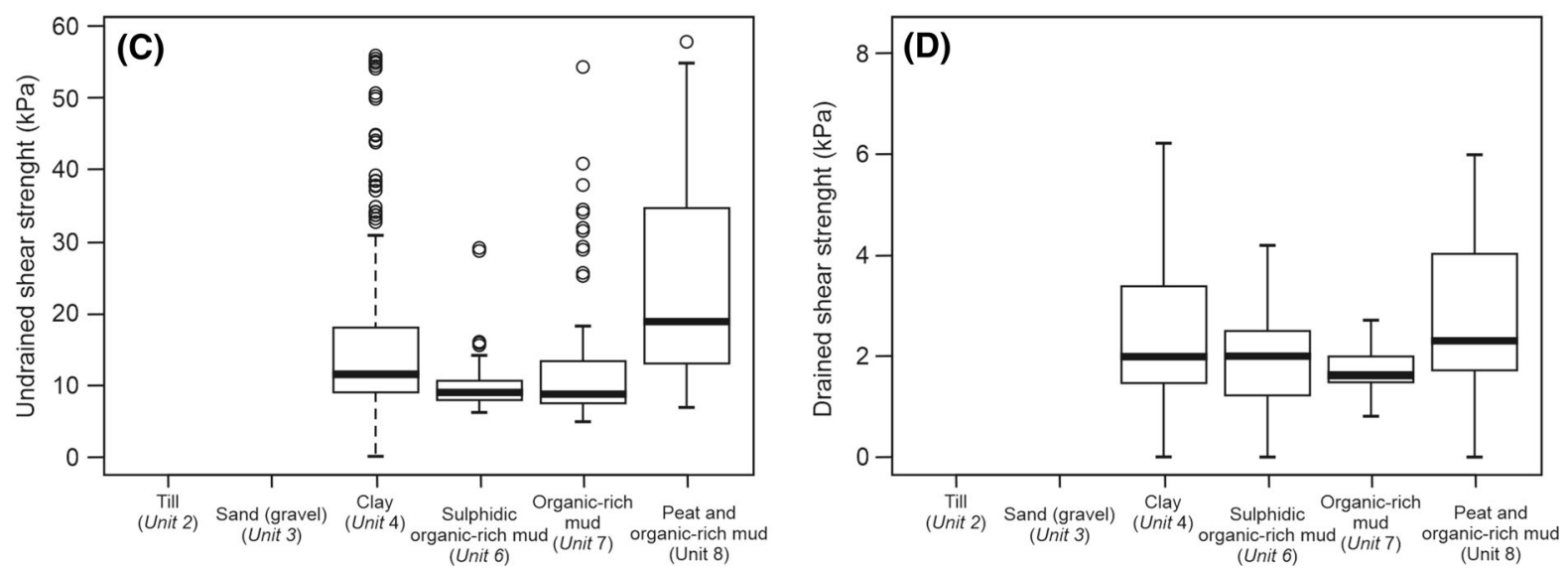

Fig. 9 Box-and-whiskers plots showing the distribution of geotechnical properties of the selected engineering-geological units 2-8 modelled for Rastaala basin in the southern Finnish coast by the Baltic Sea 

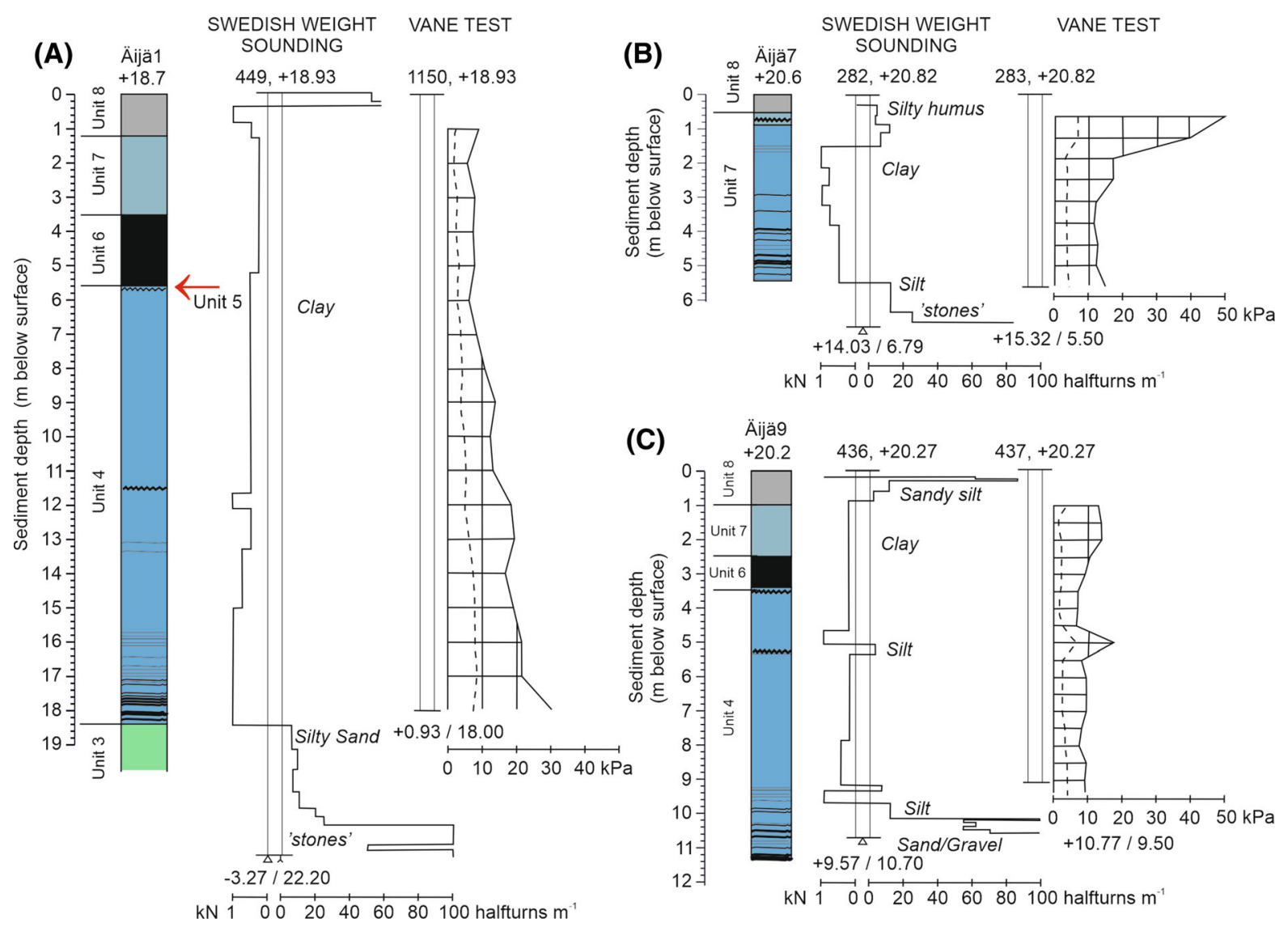

Fig. 10 Selected lithological logs of the cores Äijä1, Äijä7 and Äijä9 in the Rastaala basin (see Fig. 2) associated with the geotechnical characteristics of nearby soundings

lower part of unit 4 and the underlying sand (unit 3) is often not straightforward (see also SGF/BGS 2001). This boundary is also gradational in the lithostratigraphic sense. Likewise, the upper boundary of till (unit 2) is challenging to detect, although the penetration resistance is sometimes increased compared with the overlying sand (unit 3). According to Repo et al. (1970), the grain-size assemblage of unit 2 varies considerably in this area, which is another reason why the boundary between units 2 and 3 is difficult to detect with geotechnical drilling. However, the optimal judgement concerning the boundary between units 2 and 3 in the Rastaala case was based on several adjacent soundings in connection with the conceptual geological model and, importantly, an indicative operators note of 'stones' in a coring diagram (Fig. $10 \mathrm{a}, \mathrm{b}$ ).

Significant differences between fine-grained sediment units (units 4-8) in the Rastaala basin are also detected with shear vane tests (Fig. 9c, d). The undrained shear strength is typically higher (15-35 kPa) in the upper part (unit 8) due to the appearance of dry crust and peat. Although the strength values depend on the depth and the state of consolidation (e.g. Gardemeister 1975), it seems evident that organic-rich sediment units 6 and 7 have the lowest undrained and drained shear strength in the Rastaala basin, respectively about 10 and $2 \mathrm{kPa}$. The corresponding values for clay (unit 4) are somewhat higher (10-20 $\mathrm{kPa}$ and $2-3 \mathrm{kPa}$ ), with a broader interquartile range (Fig. 9c, d). In general, the values from the vane tests in the Rastaala basin are of the same magnitude as those given by Gardemeister (1975), who suggested that the strengths of lacustrine clay and clay sediments of the BSB in southern Finland vary between 1 and $3 \mathrm{Mp} \mathrm{m}^{-2}$, which is equivalent $10-30 \mathrm{kPa}$. In addition, the strength values are typically two times higher $\left(2-6 \mathrm{Mp} \mathrm{m}^{-2}\right.$, i.e. 
20-60 kPa) in the lower part of the fine-grained deposits, where the frequency and thickness of silt (sandy silt) layers often increase with depth. This behaviour is very distinct in the Rastaala study area, where shear strength increases in the lower part of unit 4 (Fig. 10a) and where statistics indicate scattered high $(>30 \mathrm{kPa})$ values of undrained shear strength in unit 4 (Fig. 9c).

While the overall distribution and thickness of finegrained sediments are often well constrained with Swedish weight soundings for civil engineering purposes, the spatial distribution of organic-rich sediments and their internal structure, composition, and engineering-geological properties are in many cases poorly presented and understood. As demonstrated by Gardemeister (1975), the strength and consolidation properties of fine-grained sediments in Finland are most significantly influenced by the contents of clay and humus, and they can thereby be further separated into different classes. In an allostratigraphic approach to several sediment sections in southern coastal Finland, Ojala et al. (2018), correspondently with Gardemeister (1975), divided the fine-grained sequences into two parts: overlying brackish-water muds and underlying postglacial lacustrine clayey sediments that are separated by an unconformity. This approach was also applied in the present study by using lithostratigraphic logs and an allostratigraphic approach, as discussed above (Figs. 3, 4). The engineering-geological significance of this division is that soft organic-rich sediments (units 6,7 and 8) often have an appreciably greater plasticity index and liquid limits than more stiff clayey sediments (unit 4) lying underneath (Gardemeister 1975). Notably, these organic-rich sediments often contain naturally elevated concentrations of sulphide (unit 6), which, as potential acid sulphate soils, may cause a potential risk to the environment and underground steel and concrete constructions due to acidification when exposed to oxic conditions (e.g. Åström and Björklund 1997; Andersson and Norrman 2004). In addition, these sulphide-containing organic-rich brackish-water muds are generally less easy to stabilise using cement-lime binders than sections with late- and postglacial clays (Törnqvist 2008). Based on the results displayed in Figs. 6, 7 and 10 the distribution of sulphide-bearing unit 6 is spatially limited in the Rastaala basin, as discussed above.
Another feature of the Rastaala basin is that redeposition of silt and sand has played a significant role in the formation of the overall stratigraphy. In particular, the mid-Holocene marine flooding and associated short-lived Litorina Sea transgression caused significant erosion, winnowing and redistribution of material from local coarse-grained deposits in the area, and resulted in the deposition of the transgressive shelf sand sheet on the base of the brackish-water mud (Virtasalo et al. 2016). The thickness and distribution of this sand sheet (unit 5) was strongly influenced by topography and the availability of sand in local deposits. Storm reworking of the sandy deposits initiated before and continued after the Litorina transgression in the shallow Rastaala basin, as is demonstrated by the occurrence of sandy silt tongues toward the central depression (Fig. 5). The engineering-geological significance of unit 5 is that the reworked sand is exposed at the surface on the slopes of hills, but appears as complex interlayers within and between units 4 and 6 towards the basin centre, as clearly registered by Swedish weight soundings with a higher penetration resistance (Fig. 6). The penetration of this unit typically requires a number of half turns of the sounding rods and is often associated with the operator notation of 'silt' or 'sand' interlayers in the drilling diagrams (Figs. 6, 10c). Combined with a conceptual geological model, these pieces of drilling information complete the identification of unit 5 in the Rastaala basin. Typical characteristics of unit 5 are that it is discontinuous and that at a higher elevation the unit is thicker and composed of fine sand, whereas at lower elevations the unit becomes thinner and the material generally finer (silt) towards the central part of the basin. This appearance is related to sediment transport and redeposition in a bedded or suspended form, which is interlinked with the bottom dynamics and material properties (e.g. Håkanson and Jansson 1983). As in many places in the study area, unit 5 is underlain by fine-grained sediments (unit 4), which causes challenges for construction and land use.

\section{Conclusions}

The approach presented in this paper comprises the stepwise integration of 2D geological maps, a conceptual geological model and geotechnical drillings 
into a 3D representation of the shallow subsurface stratigraphy in the coastal area of the Baltic Sea Basin. The most important outcomes that emerge from the study are as follows:

(1) The selection of sediment units for the Rastaala basin 3D model was based on sediment lithostratigraphy and geotechnical properties. The sediments contained two alloformations and were divided into eight engineering-geological sediment units for the modelling.

(2) Stepwise modelling with multi-source data integration and the cross-section approach (BGS Groundhog ${ }^{\circledR}$ Desktop Copyright (C) BGS/NERC 2019) was found to be very suitable in a basin environment where glacial sediments are covered by fine-grained sediments of the BSB. Two independent 3D models, created with different platforms (Emerson E\&P SKUA-GOCAD ${ }^{\mathrm{TM}}$ _Paradigm ${ }^{\circledR}$ and Leapfrog $($ ), provided closely similar solids and surfaces, which was probably due to the large number and extensive spatial distribution of sample points in the Rastaala study area.

(3) A comparison between 3D model(s) and soundings data provided general statistical characteristics regarding the engineering-geological properties of the selected units, including penetration resistance and shear strength, which can be applied for correlative sediment units at different locations in the costal Baltic Sea region.

(4) The detection and spatial distribution of potential acid sulphate sediments requires lithological $\operatorname{logs}$ (and quantitative chemical analysis), although the shear strength of the sediments seems to be anomalously low in the Rastaala basin.

Acknowledgements We thank Jouni Rautiainen, Matti Kaurila and the city of Espoo for providing the geotechnical drillings. Two anonymous reviewers are acknowledged for their critical and helpful comments and Niko Putkinen for fruitful discussions and help with 3D modelling.

\section{Declaration}

Conflicts of interest The authors declare no conflict of interest.
Open Access This article is licensed under a Creative Commons Attribution 4.0 International License, which permits use, sharing, adaptation, distribution and reproduction in any medium or format, as long as you give appropriate credit to the original author(s) and the source, provide a link to the Creative Commons licence, and indicate if changes were made. The images or other third party material in this article are included in the article's Creative Commons licence, unless indicated otherwise in a credit line to the material. If material is not included in the article's Creative Commons licence and your intended use is not permitted by statutory regulation or exceeds the permitted use, you will need to obtain permission directly from the copyright holder. To view a copy of this licence, visit http://creativecommons.org/licenses/by/4.0/.

\section{References}

Andersson M, Norrman T (2004) Stabilisering a sulfidjord-En litteratur-ocv labortatiriestudie. Luleå tekniska Universitet, Examensarbete 2004: 126 CIV, p 38

Åström M, Björklund A (1997) Geochemistry and acidity of sulphide bearing postglacial sediments of western Finland. Environm Geochem and Health 19:155-164

Bennett MR, Glasser NF (2009) Glacial geology: ice sheets and landforms, 2nd edn. Wiley-Blackwell, Oxford, p 385

Bouchard MA, Gibbard PL, Salonen V-P (1990) Lithostratotypes for weichselian and pre-weichselian sediments in southern and western Finland. Bull Geol Soc Finland 62:79-95

Cavero J, Orellana NH, Yemez I, Singh V, Izaguirre E (2016) Importance of conceptual geological models in 3D reservoir modelling. EAGE First Break 34:39-49

Collon P, Steckiewicz-Laurent W, Pellerin J, Laurent G, Caumon G, Reichart G, Vaute L (2015) 3D geomodelling combining implicit surfaces and Voronoi-based remeshing: a case study in the Lorraine Coal Basin (France). Comput Geosci 77:29-43

Culshaw MG (2005) From concept towards reality: developing the attributed 3D geological model of the shallow subsurface. Quarterly J Eng Geol Hydrogeol 38:231-284

De Geer G (1912) A geochronology of the last 12000 years. In: Compte Rendu 11, Congress Geologique International, 11th International Geological Congress (1910), Stockholm, Sweden, vol. 1, p 241-253

Devleeschouwer X, Pouriel F (2006) Brussels Urban Geology (BUG): a 2D and 3D model of the underground by means of GIS. The Geological Society of London, IAEG2006 Paper number 420

Donner J (1995) The Quaternary History of Scandinavia. Cambridge, New York, p 200

Edén P, Weppling K, Jokela S (1999) Natural and land-use induced load of acidity, metals, humus and suspended matter in Lestijoki, a river in western Finland. Boreal Env Res 4:31-43

El May M, Dlala M, Chenini I (2010) Urban geological mapping: Geotechnical data analysis for rational development planning. Engineering Geol 116:129-138

Evans R (2003) Current themes, issues and challenges concerning the prediction of subsurface conditions. In: 
Rosenbaum MS, Turner AK (eds) New paradigms in subsurface prediction: characterisation of the shallow subsurface: implications for urban infrastructure and environmental assessment. Springer-Verlag, Düsseldorf, pp 359-378

Evans DJA, Benn DI (eds) (2004) A Practical Guide to the Study of Glacial Sediments. Oxford University Press, New York, p 266

Fang H-Y, Daniels JL (2006) Introductory Geotechnical Engineering, an Environmental Perspective. Spon Press, New York, p 546

Fookes PG (1997) Geology for engineers: the geological model, prediction and performance. Quaterly J Eng Geol 30:293-424

Gardemeister R (1975) On the engineering-geological properties of fine-grained sediments in Finland. Tech Res Centre of Finland, Build technol commun develop, Publ 9:91

Håkanson L, Jansson M (1983) Principles of lake sedimentology. Springer-Verlag, Berlin, p 316

Hirvas H (1991) Pleistocenestratigraphy of Finnish Lapland. Geol Surv Finland, Bulletin 354:123

Hirvas H, Nenonen K (1987) The till stratigraphy of Finland. Geol Surv Finland Spec Pap 3:49-63

Hirvas H, Lintinen P, Lunkka JP, Erikson B, Grönlund T (1995) Sedimentation and lithostratigraphy of the Vuosaari multiple till sequence in Helsinki, southern Finland. Bull Geol Soc Finland 67:51-64

Hyttinen O, Kotilainen AT, Virtasalo JJ, Kekäläinen P, Snowball I, Obrochta S, Andrén T (2017) Holocene stratigraphy of the Angermanälven River estuary, Bothnian Sea. GeoMar Lett 37:273-288

Hyvärinen H (1980) Relative sea-level changes near Helsinki, southern Finland, during early Litorina times. Bull Geol Soc Finland 52:207-219

Hyvärinen H (1999) Shore displacement and stoneage dwelling sites near Helsinki, southern coast of Finland. In: Huurre M (ed) Digit all: papers dedicated to Ari Siiriäinen. Finnish Antiquarian Society, Archaeological Society of Finland, Helsinki, pp 79-89

Jensen JB, Moros M, Endler R, IODP Expedition 347 Members (2017) The Bornholm Basin, southern Scandinavia: a complex history from Late Cretaceous structural developments to recent sedimentation, Boreas 46:3-17

Jokinen SA, Virtasalo JJ, Kotilainen AT, Saarinen T (2015) Varve microfabric record of seasonal sedimentation and bottom flow-modulated mud deposition in the coastal northern Baltic Sea. Mar Geol 366:79-96

Kakkuri J (2012) Fennoscandian land uplift: past, present and future. In: Haapala I (ed) From the Earth's core to outer space. Springer, Dordrecht, pp 127-136

Kessler H, Turner AK, Culshaw M, Royse K (2008) Unlocking the potential of digital 3D geological subsurface models for geotechnical engineers. Cities and their underground environment: 2nd European conference of International Association of engineering geology. Euroengeo 2008, Madrid, Spain, 15-20 Sept 2008

Knill J (2003) Core values: the first Hans-Cloos lecture. Bull Eng Geol Environm 62:1-34

Laitala M (1991) Pre-Quaternary rocks of the Helsinki mapsheet area. Geological Map of Finland 1:100 000,
Explanation to the Maps of Pre-Quaternary rocks, sheet 2034. Geological Survey of Finland, Espoo

Matildes R, Taborda R, Almeida IM (2010) 3D geological model of Lisbon. In: Williams AL, Pinches GM, Chin CY, McMorran TJ, Massey CI (eds) Geologically active. Taylor \& Francis Group, London, pp 2201-2208

NACSN $=$ North American Commission on Stratigraphic Nomenclature (2005) North American stratigraphic code. AAPG Bulletin 89: 1547-1591

Nuorteva J (1994) Topographically influenced sedimentation in Quaternary deposits - a detailed acoustic study from the western part of the Gulf of Finland. Geol Surv Finland, Report of Invest 122:88

Ojala AEK (2011) Construction suitability and 3D architecture of the fine-grained deposits in southern Finland - examples from Espoo. In: Nenonen K, Nurmi P (eds) Geoscience for Society-125th anniversary volume, Geological Survey of Finland, Espoo, Special Paper 49, pp 205-212

Ojala AEK, Palmu J-P, Åberg A, Åberg S, Virkki H (2013) Development of an ancient shoreline database to reconstruct the Litorina Sea maximum extension and the highest shoreline of the Baltic Sea basin in Finland. Bull Geol Soc Finland 85:127-144

Ojala AEK, Saresma M, Virtasalo JJ, Huotari-Halkosaari T (2018) An allostratigraphic approach to subdivide finegrained sediments for urban planning. Bull Eng Geol Environm 77:879-892

Pajunen M, Airo M-L, Elminen T, Niemelä R, Salmelainen J, Vaarma M, Wasenius P, Wennerström M (2008) Construction suitability of bedrock in the Helsinki area based on the tectonic structure of the Svecofennian crust of southern Finland. Geol Surv Finland Spec Pap 47:309-326

Rainio H, Lahermo P (1976) Observations on dark grey basal till in Finland. Bull Geol Soc Finland 48:137-152

Räsänen ME, Auri JM, Huitti JV, Klap AK, Virtasalo JJ (2009) A shift from lithostratigraphic to allostratigraphic classification of Quaternary glacial deposits. GSA Today 19:4-11

Repo R, Valovirta V, Rainio H (1970) Explanation to Maps of Superficial Deposits, 1:100 000, Sheet 2032

Salvador A (ed) (1994) International Stratigraphic Guide. Trondheim, and the Geological Society of America, Boulder, International Union of Geological Sciences, p 214

Sauramo M (1923) Studies on Quaternary varve sediments in southern Finland. Bulletin de la Commission Géologique de Finlande 60:164

SGF/BGS (2001) System of notations for geotechnical investigations. Swedish Geotechnical Society (SGF) and Society of Engineering Geology (BGS), p 61

Stapelfeldt T, Lojander M, Tanska H, Ojala A, Forsman J (2009) Deep stabilised test embankment at the Suurpelto area in Espoo, Southern Finland. In: Karstunen M, Leoni M (eds) Geotechnics of Soft Soils - Focus on Ground Improvement. Taylor \& Francis Group, London, pp 423-428

Stroeven AP, Hättestrand C, Kleman J, Heyman J, Fabel D, Fredin O, Goodfellow BW, Harbor JM, Jansen JD, Olsen L, Caffee MW, Fink D, Lundqvist J, Rosqvist GC, Strömberg B, Jansson KN (2016) Deglaciation of Fennoscandia. Quat Sci Rev 147:91-121

Sturm M (1979) Origin and composition of clastic varves. In: Schlüchter C (ed) Moraines and Varves: Origin, Genesis, Classification. A.A, Balkema, Rotterdam, pp 281-285 
Svendsen JI, Alexanderson H, Astakhov VI, Demidov I, Dowdeswell JA, Funder S, Gataullin V, Henriksen M, Hjort C, Houmark-Nielsen M, Hubberten HW, Ingólfsson Ó, Jakobsson M, Kjær KH, Larsen E, Lokrantz H, Lunkka JP, Lyså A, Mangerud M, Matiouchkov A, Murray A, Möller P, Niessen F, Nikolskaya O, Polyak L, Saarnisto M, Siegert C, Siegert MJ, Spielhagen R, Stein R (2004) Late Quaternary ice sheet history of northern Eurasia. Quat Sci Rev 23:1229-1271

Törnqvist J (2008) Suurpellon sulfidisavien vaikutukset paalujen ja maanvastaisten betonilaattojen kestoikään ja teräsrakenteiden pysyvyyteen (in Finnish). Tutkimusselostus nro VTT-S-00621-08, p 23

Tsyrulnikov A, Tuuling I, Kalm V, Hang T, Flodén T (2012) Late Weichselian and Holocene seismostratigraphy and depositional history of the Gulf of Riga, NE Baltic Sea. Boreas 41:673-689

Virtasalo JJ, Kotilainen AT, Räsänen ME, Ojala AEK (2007) Late-glacial and post-glacial deposition in a large, low relief, epicontinental basin: the northern Baltic Sea. Sedimentology 54:1323-1344

Virtasalo JJ, Löwemark L, Papunen H, Kotilainen AT, Whitehouse MJ (2010) Pyritic and baritic burrows and microbial filaments in postglacial lacustrine clays in the northern Baltic Sea. J Geol Soc London 167:1185-1198

Virtasalo JJ, Bonsdorff E, Moros M, Kabel K, Kotilainen AT, Ryabchuk D, Kallonen A, Hämäläinen K (2011) Ichnological trends along an open-water transect across a large marginal-marine epicontinental basin, the modern Baltic Sea. Sedimentary Geol 241:40-51

Virtasalo JJ, Hämäläinen J, Kotilainen AT (2014a) Toward a standard stratigraphical classification practice for the
Baltic Sea sediments: the CUAL approach. Boreas 43:924-938

Virtasalo JJ, Ryabchuk D, Kotilainen AT, Zhamoida V, Grigoriev A, Sivkov V, Dorokhova E (2014b) Middle Holocene to present sedimentary environment in the easternmost Gulf of Finland (Baltic Sea) and the birth of the Neva River. Marine Geol 350:84-96

Virtasalo JJ, Endler M, Moros M, Jokinen SA, Hämäläinen J, Kotilainen AT (2016) Base of brackish-water mud as key regional stratigraphic marker of mid-Holocene marine flooding of the Baltic Sea Basin. Geo-Mar Lett 36:445-456

Virtasalo JJ, Schröder JF, Luoma S, Majaniemi J, Mursu J, Scholten J (2019) Submarine groundwater discharge site in the First Salpausselkä ice-marginal formation, south Finland. Solid Earth 10:405-423

Wang Z, Qu H, Wu Z, Wang X (2018) Geo3DML: A standardbased exchange format for 3D geological models. Comput Geosci 110:54-64

Wu Q, Xu H, Zou X (2005) An effective method for 3D geological modelling with multi-source data integration. Comput Geosci 31:35-43

Yan-lin S, Ai-ling Z, You-bin H, Ke-yan X (2011) 3D Geological modeling and its application under complex geological conditions. Procedia Eng 12:41-46

Zolitschka B, Francus P, Ojala AEK, Schimmelmann A (2015) Varves in lake sediments - a review. Quat Sci Rev $117: 1-41$

Publisher's Note Springer Nature remains neutral with regard to jurisdictional claims in published maps and institutional affiliations. 